\title{
Birth outcomes in hard times among minority ethnic groups
}

\author{
Paola Bertoli ${ }^{1,2}$. Veronica Grembi ${ }^{3}$ The Linh Bao Nguyen ${ }^{4}$
}

Received: 8 April 2020 / Accepted: 10 February 2021 / Published online: 23 March 2021

(C) The Author(s) 2021

\begin{abstract}
Combining a unique dataset of birth records with municipal-level real estate information, we assess the impact of the 2008 recession on the health of immigrants' newborns in Italy. Health at birth (e.g., low birth weight) of children born to immigrants deteriorated more than health at birth of children born to Italian natives. The negative effects on immigrants are not equally distributed across ethnicities, but rather are driven by the main economic activity of the ethnic group and its related network at the municipal level. Immigrants whose ethnic group is mainly employed in the sectors most affected during the recession suffered the most. Living in a municipality where their ethnic network is organized through more registered immigrant associations mitigates the recession hardship for immigrants. The characteristics of ethnic groups and their organization at the municipal level do not explain the heterogeneous effects on Italian newborns, which confirms the presence of network effects rather than neighborhood effects
\end{abstract}

Keywords Recessions - Immigrants - Low birth weight · Premature babies · Networks

JEL Classification I1 $\cdot \mathrm{I} 12 \cdot \mathrm{J} 15 \cdot \mathrm{J} 60$

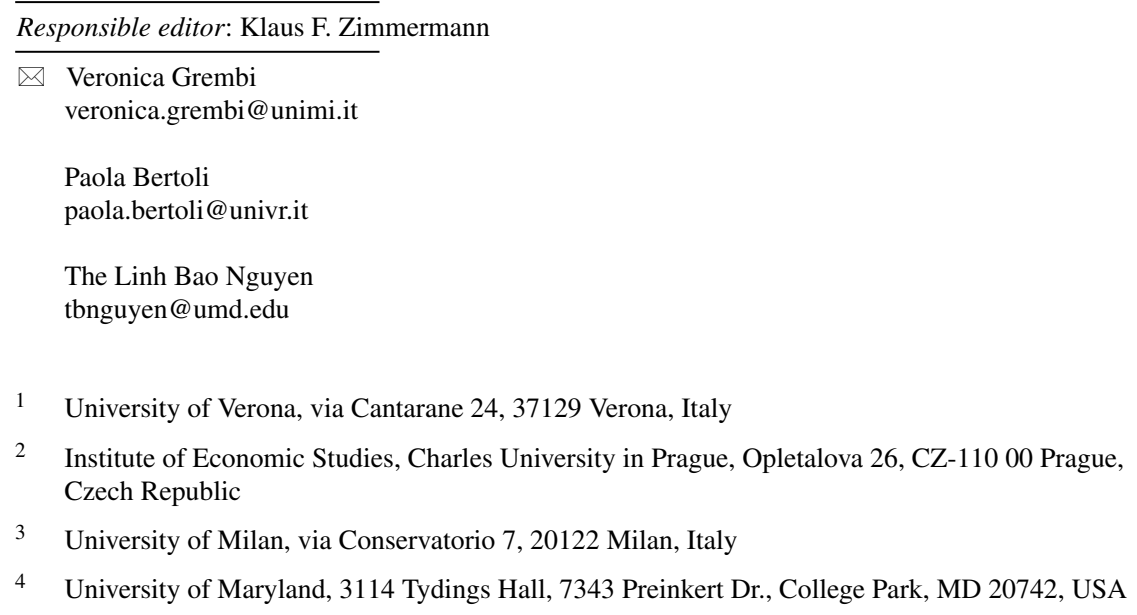




\section{Introduction}

As the first quarter of 2020 appears to be the beginning of unprecedented hard times for the economy, it is crucial to understand the potential consequences of recessions on health and the possible mitigation channels. A large body of literature that addresses the link between the business cycle and health at birth provides findings that are often conflicting. Being born in hard times seems to have a positive impact on babies' health in the US (Dehejia and Lleras-Muney 2004) and in Spain (Aparicio et al. 2020) due to selection in the fertility of women who decide to give birth despite a recession. Being born in hard times increases the probability of subsequent negative outcomes for babies born during a recession in the Netherlands, Germany or Greece (van den Berg et al. 2009; van den Berg et al. 2016), while it has no effect on the birth weights of Swedish babies (van den Berg and Modin 2013), a measure used to predict health in adulthood. However, being born in hard times has a negative impact on the health of UK newborns (De Cao et al. 2019). This negative impact also occured, absent a fertility selection mechanism, during the 2001 Argentinian crisis analyzed (Bozzoli and Quintana-Domeque 2014). To date, the literature has mainly examined the socioeconomic status of mothers-to-be, as proxied by their education, to investigate the heterogeneous effects of the cycle on health, but this has not reconciled the mixed evidence.

We contribute to this debate by analyzing the effects of the 2008 recession on the health at birth of immigrants' newborns using a unique dataset of 540,000 births that were conceived between 2002 and 2013. We improve the existing evidence in three ways. First, we focus on a specific episode - the 2008 recession - which had clear expected effects on the labor market. As pointed out by Hoynes et al. (2012), the effects of the Great Recession (GR) were stronger than previous recessions for certain socioeconomic groups: more fragile groups and the groups more involved in the industry most affected by the recession suffered the most. Second, we propose a more in-depth investigation of the channels of the average effects. Third, to our knowledge, this is the first work to shed light on the effect of the GR on infant health in Italy. Although a vast number of studies in the literature have examined how the GR impacted Italian adults' health (De Vogli et al. 2014; Mattei et al. 2014 ; Moscone et al. 2016; Di Pietro 2018; Cavicchioli and Pistoresi 2019, D'Errico et al. 2019, Caltabiano et al. 2017) previous works on infant health either approach the topic from a cross-country perspective (Ensor et al. 2010; Angelini and Mierau 2014) or examine the effect of macroeconomic conditions rather than the effect of the GR (Cavalieri and Ferrante 2016; Simeoni et al. 2019).

We identify the spread of the GR across Italian municipalities by exploiting information on the prices per square meter of commercial real estate (e.g., stores) at the municipal level. The prices of commercial real estate capture the GR spread without necessarily suffering from reverse causation problems on fertility like unemployment rates (Schaller 2016) and residential real estate prices (Dettling and Kearney 2014). We use the growth rates of commercial real estate prices to define the status of a treated municipality in a staggered difference-in-differences setting through 
which we proxy the spread of the intensity of the crisis. Our granular data allow us to more precisely capture the dynamic of the GR with respect to local idiosyncratic economic shocks rather than economic shocks driven by broader macro conditions, which would occur, for instance, when using the state level (Lindo 2015).

The GR deteriorated health at birth, along the main proxies used in the literature, for both immigrants' and Italians' newborns with a stronger impact on immigrants' newborns. The incidence of low birth weight increased by $+8.7 \%$ (at the mean of low birth weight), the incidence of very low birth weight increased by $+36 \%$, and the incidence of preterm babies increased by $+8.3 \%$ in our preferred specification. We do not find these results to be driven by a change in fertility. These effects are robust to the use of several sets of covariates and fixed effects at the municipal and ethnic group levels through which we control for language proximity and cultural differences in the use of prenatal care. The impact of the recession on immigrants' babies is significantly larger than the impact of the recession on Italians' babies, for whom there is an increase by $5.3 \%$ in the probability of being low birth weight, an increase by $21 \%$ of being very low birth weight, and an increase by $3.8 \%$ of being preterm at the mean of each variable.

We examine the channels of the effects on immigrants by exploiting the organization of their ethnic network. The economic literature shows that being in a strong ethnic network, as proxied by geographical ethnic concentration indexes, helps immigrants find a job and earn higher wages (see e.g., Edin et al. 2003; Damm 2009; Xie and Gough 2011; Patacchini and Zenou 2012), which might have a positive impact on health. However, being in a strong network decreases the incentives to invest in human capital (e.g., Battisti et al. 2018) and may also restrict out-of-network employment opportunities, which generates a type of lock-in situation. These elements might reinforce the negative impact of a recession.

We proxy ethnic networks for newborns by using three sets of measures based on their ethnic group size (e.g., the demographic incidence of each group), the organization of the immigrant community in the municipality of birth (e.g., the number of registered associations), and the diversification among the sectors of employment of each group (e.g., manufacturing or construction as the main sectors of employment).

A higher number of register associations (or their proximity) at the municipal level and a higher diversification among the sectors of employment of each ethnicity buffered the negative effects of the recession. Babies born in a municipality closer to an immigrant association (or where there were more associations) were less likely to have worse health outcomes at birth. This is consistent with the fact that approximately $60 \%$ of immigrant associations in Italy are active in the area of social assistance and provide medical and psychological support services (Frisanco 2006). The average negative impact on immigrants' newborns is driven by the ethnic groups that are more concentrated in the sectors mainly affected by the crisis and that have fewer outside options in the labor market. In contrast, the size of the ethnic network did not exert any role. These results are robust to the inclusion of municipality fixed effects to capture the time-invariant attitudes towards immigrants that could affect the registration of an immigrant association or the settling of a specific ethnic group. In 
addition, we do not find these channels to have differential effects on Italian babies, which suggests the importance of network effects rather than neighborhood effects.

Although the results driven by a higher concentration of employment in manufacturing and construction are quite intuitive, we further investigate the positive effects of immigrant associations (or their proximity) to check if they might be related to any composition effect of immigrant communities. For municipalities closer to an immigrant association, we estimate an increase of the healthiest ethnic groups (see Chiswick 1999; Farré 2015) and of the groups that use more prenatal care, although this last effect is not always precisely estimated. Finally, we find less in utero selection of baby boys. This finding is important because it has been shown that exposure to psychological and economic distress during pregnancy increases the probability that more baby girls will be born over baby boys, which could explain the increase in the incidence of low-weight newborns during recessions.

Our results have two main implications. First, minorities suffer more during a significant recession, which should be kept in mind when designing policy interventions. Second, if interventions prioritize minorities more involved in the most affected economic sectors, they should also exploit the work of immigrant associations and ultimately consider favoring their activities in areas that are the most deprived of these associations.

This paper is organized as follows. Section 2 describes the main features, the timeline of the GR in Italy and the approach that we use to proxy its spread across Italian municipalities. Section 3 provides a description of our dataset and the main outcomes of interest. Section 4 describes the econometric specification and the average results, while Section 5 defines the ethnic drivers and their effects. Section 6 concludes.

\section{The great recession in Italy and how to measure it}

Italy was among the European countries most affected by the GR, along with Greece, Spain, and Portugal (Lin et al. 2013). The crisis began during the second quarter of 2008 , when a $1.9 \%$ drop in GDP was accompanied by a $2 \%$ contraction in consumption, a $7.4 \%$ fall in exports, and an $8.9 \%$ decrease in investment (Busalacchi et al. 2009). The manufacturing industry and the construction sector were among the sectors most affected by the crisis, whose negative impact was especially felt in northern and central Italy (Eurofond 2010). In 2010, the national economy seemed to register a mild improvement. However, in the summer of 2011, the crisis resurged through a sharp increase in the national bond yield. The weak GDP recovery of less than $1 \%$ in 2010 was then followed by a severe drop of almost $9 \%$ during the 2011-2014 period. Overall, the labor market suffered similar trends to the GDP trends, with the first clear growth in the unemployment rate occurring in 2008 and a second increase occurring in 2011, as shown in Fig. 1.

In the literature on health at birth and the business cycle, the cycle is usually proxied by unemployment rates, but this could be problematic in our setting. For the unemployment rate to be meaningful, the level of aggregation is generally higher than 


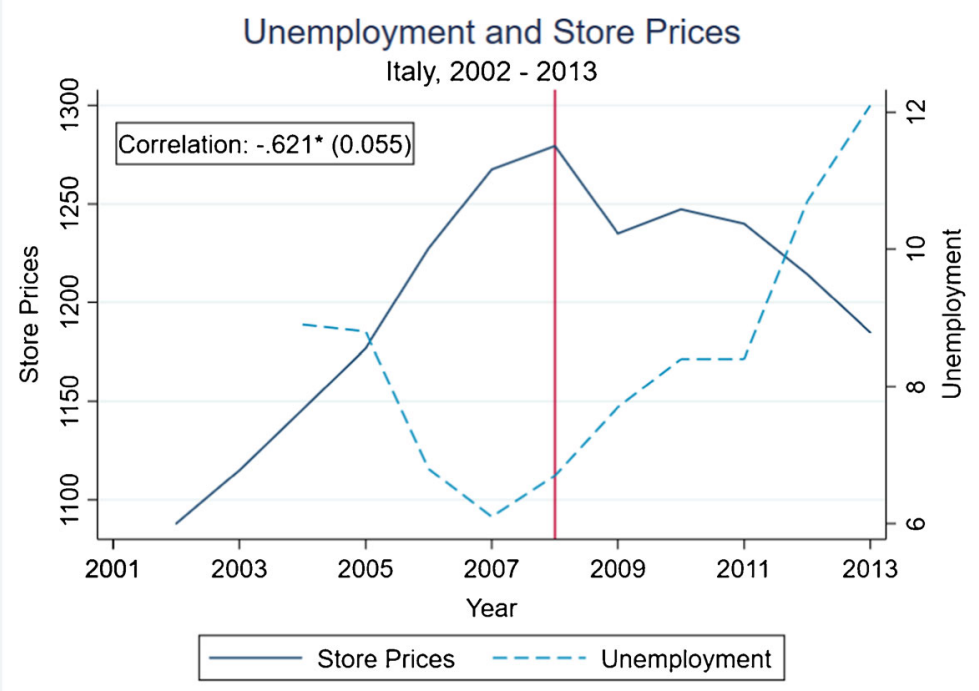

Fig. 1 Treatment and unemployment. Notes: The figure combines data on the unemployment rate as recorded at the provincial level and store prices per square meter at the municipal level

the municipal level. ${ }^{1}$ Moreover, unemployment can be endogenous to fertility decisions and behavioral decisions on how much to invest in the quality of the offspring. For these reasons, Dettling and Kearney (2014) propose an alternative measure: the prices of residential real estate. However, residential real estate prices also create identification concerns, with people who are most likely to have a baby also being the most likely to buy a house (rather than renting one). Therefore, as a measure of the economic cycle experienced by the population at large (i.e., natives and immigrants), we use commercial real estate prices that are expected to be less prone to endogeneity problems than residential real estate prices and unemployment. ${ }^{2}$

Through the Observatory of Real Estate Transactions (Osservatorio del Mercato Immobiliare) of the Italian Land Agency, we collected data on the prices of stores. ${ }^{3}$ For each municipality, the Observatory provides the maximum and minimum sales price per square meter, which are based on the transaction flow of the clusters of predefined stores, per type of municipal area and commercial position. Then, we take

\footnotetext{
${ }^{1} \mathrm{~A}$ recent attempt to construct a more granular level of unemployment is in De Cao et al. (2019). The authors exploit the requests for unemployment-related benefits in the Middle Layer Super Output Areas (MSOAs) in England to proxy for the unemployment level.

${ }^{2}$ Additionally, as a point of comparison with the previous literature, we carry out the same analysis, but we use residential prices instead of commercial prices to capture the effects of the GR. Using housing prices leads to consistent results.

${ }^{3}$ These data are available for all Italian municipalities, except for two regions (i.e., Friuli Venezia Giulia and Trentino Alto Adige), which are omitted from our dataset.
} 

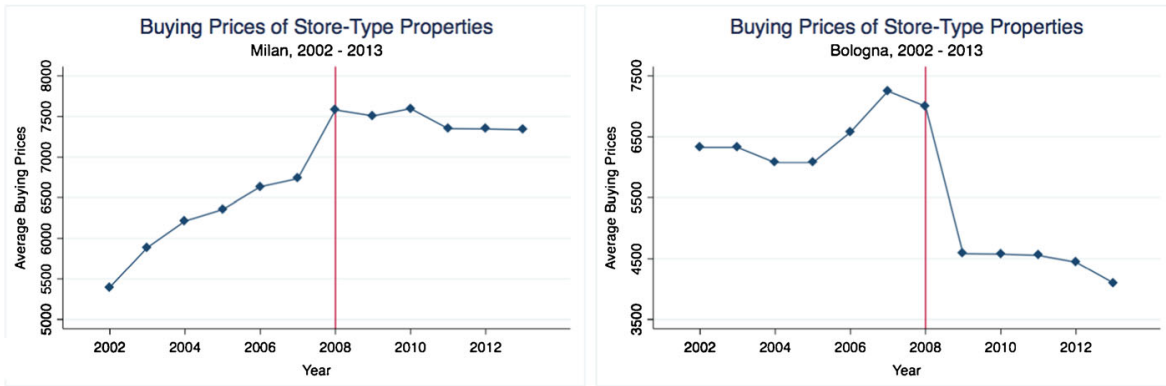

Fig. 2 Treatment across municipalities: Examples. Notes: Each figure plots the trend of store prices per square meter between 2002 and 2013. Milan is located in the north, while Bologna is in the center of the country. According to our definition of the treatment (first year in which the growth rate turns negative), Milan is considered treated in 2009 and Bologna in 2008

the mean between the maximum and minimum sales price of the stores located in central municipal areas and in normal commercial positions.

The focus on the central areas avoids the problem of a possible variation in the number of stores over time, which could affect price fluctuations through changes in the stock supply. In fact, we can assume that in the central areas of Italian municipalities, the supply of commercial locations has low elasticity: it is the type of commercial activity practiced in a store that usually changes, while new constructions are more constrained. The choice of commercial locations that have a normal economic position eliminates the risk of capturing the trends of a few stores with extremely high or low prices due to an exceptionally good or bad commercial position. That is, our treatment is not based on the price fluctuations of a store located in Cathedral Square in Milan or in Saint Mark's Square in Venice.

Although there might be a lower number of transactions during recessions, store prices provide a good proxy for the spread of the GR while focusing on the municipal level. The trend in store prices proxies well the trend in the unemployment rate measured at the provincial level, as shown in Fig. 1. As unemployment increases, the (central and normal) store prices decrease. These two measures are strongly and negatively correlated and their correlation is significant at the 0.1 level.

To capture the dynamic of the GR at the municipal level, we define a dummy, $G R$, that is equal to 1 from the first year after 2008 (2008 included) in which the growth rate of store prices turns negative for each municipality. ${ }^{4}$ This approach exploits both the within and between variation generated by the GR more accurately than the use of

\footnotetext{
${ }^{4}$ Our results are robust to alternative definitions of our $G R$ dummy as shown in Tables B1 - B4 of the working paper version of this paper (Bertoli et al. 2020) where the $G R$ dummy is defined by using different cut-offs based on the distribution of the growth rate of store prices. For example, in Table B1, $G R$ is equal to 1 from the first year after 2008 in which the decline in store prices is higher than the median of its distribution (i.e., $-6 \%$ ). The cut-off value for Table B2 coincides with the 55 th centile $(-5.3 \%)$, with the 65 th centiles $(-4.3 \%)$ for Table B3 and the 70th centiles $(-3.7 \%)$ for Table B4. As an alternative specification, in Table B5, we show the results that use the continuous version of our treatment.
} 
a continuous value of the price growth rate. Since the crisis struck the Italian economy at two moments (2008 and 2011), the dummy allows us to disregard situations in which there might be a temporary recovery of the local economy, which was canceled out by the second and more dramatic round of the crisis. Figure 2 provides an example of how our measure is constructed and how it is staggered across municipalities by using two major cities, namely, Milan in northern Italy and Bologna in central Italy. $G R$ was equal to 1 in 2009 in Milan and in 2008 in Bologna. Figure 3 shows the overall spread of the crisis across Italy based on our dummy becoming equal to 1 , which perfectly captures how the recession spread according to other sources (Di Quirico 2010).

\section{Datasets and outcomes}

Our analysis exploits several data sources, which are described in Table 8 in the Appendix. Overall, our data refer to the 2002-2013 conception period (2003-2014 delivery period) and to the municipalities of northern and central Italy. We restrict the sample to this part of the country for two reasons. First, the northern and central regions count the highest percentages of resident immigrants. During our observation period, the incidence of immigrants increased in this part of the country and it was higher than the average national level, as plotted in Fig. 5. This allows us to work on a larger and homogeneous sample: immigrants in these regions tend to be more educated, and this trend did not change due to the crisis. Second, the northern and central regions were the most affected by the crisis because they represent the most industrialized areas with the highest concentration of the two sectors that suffered the most from the GR (i.e., manufacturing and construction).

Our final sample includes data from 4,497 municipalities (approximately 56\% of all Italian municipalities), with an average size of 7,821 residents, and we can link almost 540,000 deliveries to these municipalities.

\subsection{Measures of health at birth}

From the Patient Discharge Records (i.e., Schede di Dimissione Ospedaliera) of Italian hospitals provided by the Ministry of Health, we recover the ethnicity of mothers and newborns and the information most used in the literature to assess health at birth: if the baby was less than 2,500 grams (Low weight) or less than 1,500 grams (Very low weight), and if she was born before the 37 th gestational week (Preterm). ${ }^{5}$ Obviously, these measures are related. For instance, $23 \%$ of Preterm cases are Very low weight; $85 \%$ of Preterm cases are Low weight, and $97 \%$ of

\footnotetext{
${ }^{5}$ These measures are registered for both legal and illegal immigrants. Delivery is free of charge in public hospitals, with no fear of being turned away. We keep other measures, as infant mortality, out of the analysis because we cannot recover the data on mortality within the first 30 days from birth at the municipal level. Infant mortality in Italy is extremely low.
} 


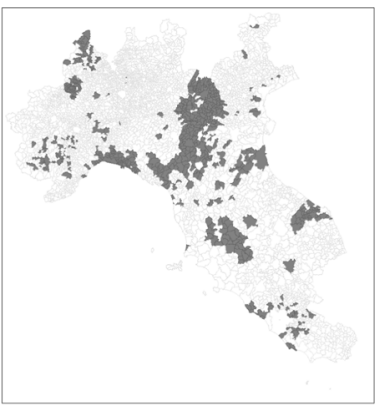

(a)

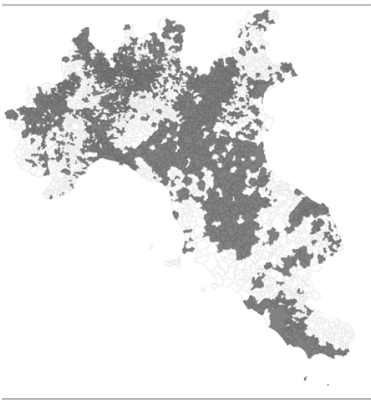

(d)

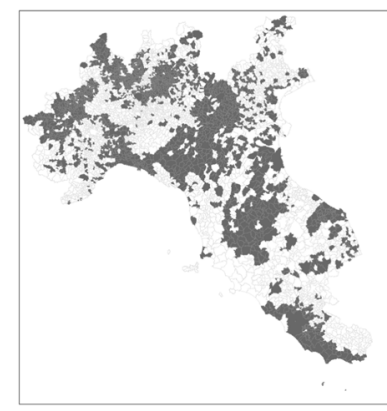

(b)

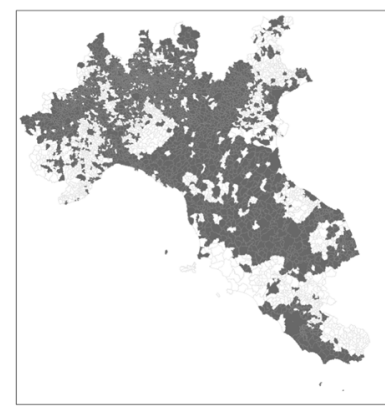

(e)

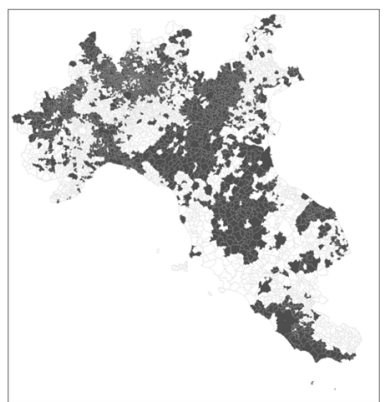

(c)

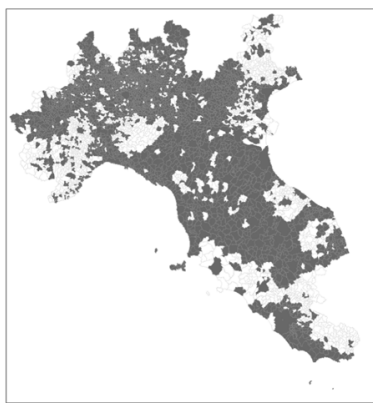

(f)

Fig. 3 Spreading of the GR. Notes: Each map represents the municipalities treated as we move from conception year 2008 to 2013. a 2008 b 2009 c 2010 d 2011 e 2012 f 2013

Very low weight are Preterm. As such, these measures should be considered to be interchangeable proxies of the same outcome: poor health at birth. In addition, being born Low Weight or Very Low Weight are predictive of health and other outcomes later on in life (Royer 2009; Helgertz and Nilsson 2019). Descriptive statistics are reported in Table 1.

These data have a few shortcomings. They do not provide any information on the socioeconomic status of the mother (e.g., the level of education or employment), and they do not allow us to know the actual consumption of prenatal care during each individual pregnancy. Additionally, we do not have information on the birth order, and consequently we cannot discuss the implications of delayed fertility versus childlessness (Currie and Schwand 2014; Brenøe and Molitor 2018; Aparicio et al. 2020).

\section{Effects on health at birth}

We estimate the impact of the spread of the GR on the health of newborn $i$ born in municipality $m$ at time $T$ and conceived in year $t$ by using the model in Eq. 1, where the prices of commercial real estate are measured at the time of conception $t$, 
Table 1 Summary statistics

\begin{tabular}{|c|c|c|}
\hline & Mean & SD \\
\hline \multicolumn{3}{|l|}{ Outcomes } \\
\hline Low weight $(<2,500 \mathrm{~g})$ & 0.084 & 0.278 \\
\hline Very low weight $(<1,500 \mathrm{~g})$ & 0.021 & 0.143 \\
\hline Preterm & 0.090 & 0.286 \\
\hline \multicolumn{3}{|l|}{ GR variables } \\
\hline Store prices & $2,760.963$ & $1,958.646$ \\
\hline House prices & $2,402.389$ & $1,651.386$ \\
\hline Unemployment & 6.047 & 2.275 \\
\hline \multicolumn{3}{|l|}{ Heterogeneous effect variables } \\
\hline Distance to the closest association & 4.887 & 6.835 \\
\hline Number of immigrant associations & 28.189 & 61.779 \\
\hline Ethnic association & 1.072 & 3.274 \\
\hline Ethnic density & 0.160 & 0.087 \\
\hline Share most educated female immigrants & 1.281 & 0.919 \\
\hline Affected sector & 9.693 & 3.739 \\
\hline Local exiting firms & 0.220 & 0.162 \\
\hline Far females on female population & 0.446 & 0.512 \\
\hline Share healthiest female immigrants & 0.547 & 0.472 \\
\hline Share females using utero selection & 0.451 & 0.195 \\
\hline \multicolumn{3}{|l|}{ Other controls } \\
\hline Share immigrant deliveries (ages 25 - 35) & 0.586 & 0.114 \\
\hline Share immigrant deliveries (ages $>35$ ) & 0.158 & 0.086 \\
\hline Share graduated & 0.074 & 0.042 \\
\hline Share high school & 0.244 & 0.047 \\
\hline Average income & $2,2497.571$ & $4,111.394$ \\
\hline Population density & $1,480.332$ & $1,886.207$ \\
\hline
\end{tabular}

See Table 8 for the description of the variables

$\gamma_{t}$ are the conception year fixed effects, $\tau_{m}$ are the municipal fixed effects, $\rho_{a}$ are the macro-areas fixed effects (i.e., North-East, North-West, and Central), and $\beta_{a}$ are the macro area trends. 6

$$
\text { Health }_{i m T}=\delta G R_{m t}+\tau_{m}+\gamma_{t}+\beta_{a}\left(\rho_{a} * t\right)+E_{m t}^{\prime} \sigma+\epsilon_{i m T}
$$

\footnotetext{
${ }^{6}$ Since the data on health at birth are the only information available at the individual level, we also estimated (1) at the aggregate/municipal level. The results are shown in Table B6 in the working paper version of this paper (Bertoli et al. 2020) and are consistent with the individual analysis.
} 
$E_{m t}^{\prime}$ groups the controls for education at the municipal level (i.e. the percentage of college graduates and percentage of high school graduates). Standard errors are clustered at the municipal level to address possible serial correlation problems (Bertrand et al. 2004). ${ }^{7}$ We consider two samples: the sample with all deliveries and the sample of singletons, as multiple pregnancies (i.e., two or more babies) naturally increase the probability of being born at a low weight or preterm. The results on the singletons are our preferred results, but we obtain similar results in the overall sample as reported in Table 9.

As shown in Table 2, the GR worsens the health of newborns; it increases the probability of being low weight by $8.7 \%$ at the mean of the variable and the probability of being very low weight by $36 \%$, while the magnitude of the effect on premature babies is $+8.3 \%$ (Column 1 ).

Our results are not associated with a change in the fertility rates of immigrants (Table 7), and they are robust to several checks. In column (2), we add two controls for maternal age (i.e., the percentage of mothers who deliver a baby between 25 and 35 years of age and the percentage of mothers older than 35) and we control for the municipal average income in column (3). Column (4) presents the results when we include ethnicity fixed effects to control for the time-invariant characteristics linked to a baby's ethnicity that could affect her health, as the traditional consumption of prenatal care. We control for population density in column (5) to account for the fact that wealthy areas might be more densely populated. The specification in column (6) includes all controls together, that is, both controls for maternal age, the municipal average income and population density. In column (7), we control for regional trends to account for geographical differences in health services and for restrictions to health care services due to the crisis, which, in Italy, are provided by regions. According to this last specification, the crisis increased the probability to be born with low weight by $7.5 \%$, very low weight by $30 \%$, and preterm by $6.9 \%$. When testing the same model on Italians' newborns, we detect a similar negative effect on health but with a lower magnitude: $a+4.9 \%$ increase in the likelihood to be low weight, $+21 \%$ increase in the likelihood to be very low weight, and $3.3 \%$ to be preterm (Table 11). ${ }^{8}$

\footnotetext{
${ }^{7}$ As a robustness check, the standard errors have also been clustered at the municipality and local health authority level (LHA) since most decisions related to healthcare are taken at the LHA level rather than at the municipal level. In fact, LHAs are health districts that group municipalities and run their own hospitals and local clinics or buy health services from independent public hospitals or private-accredited hospitals. The results of this robustness check are reported in Table 10 and are consistent with our main findings.

${ }^{8}$ In Table B7 of the working paper version (Bertoli et al. 2020), we test for the significance of the difference of the impact in the two groups, which shows that the estimated effects are statistically different. In the working paper, we also examine the effect of the GR on the full sample of Italians' newborns (Table B8) and on the entire population. As shown in Table B9 the GR increases the probability to be born with low weight, very low weight and preterm for all babies in the country. These findings are in line with the experience observed in other countries such as in India (Bhalotra 2010) and Argentina (Bozzoli and Quintana-Domeque 2014). Still, the literature has also found opposite results as in the cases of the US (Dehejia and Lleras-Muney 2004) and Spain ((Aparicio et al. 2020)) or no significant outcomes as in the case of Sweden (van den Berg and Modin 2013). Our findings also complement previous studies that show that the GR deteriorates the health conditions and health behaviors in Italy at large (Mental health: Mattei et al. 2014; Moscone et al. 2016; Changes in health behaviors: Di Pietro 2018.
} 
Table 2 Effects of the GR on birth outcomes - Single deliveries sample

\begin{tabular}{|c|c|c|c|c|c|c|c|}
\hline & (1) & $(2)$ & (3) & (4) & $(5)$ & (6) & (7) \\
\hline \multicolumn{8}{|c|}{ Panel A: Low weight $(<2,500 \mathrm{~g})$} \\
\hline Crisis & $\begin{array}{l}0.736 * * \\
(0.374)\end{array}$ & $\begin{array}{l}0.732 * \\
(0.375)\end{array}$ & $\begin{array}{l}0.706 * * \\
(0.348)\end{array}$ & $\begin{array}{l}0.750 * * \\
(0.373)\end{array}$ & $\begin{array}{l}0.701 * \\
(0.376)\end{array}$ & $\begin{array}{l}0.715 * * \\
(0.345)\end{array}$ & $\begin{array}{l}0.630 * \\
(0.328)\end{array}$ \\
\hline Mean & 8.433 & 8.433 & 8.433 & 8.433 & 8.433 & 8.433 & 8.433 \\
\hline \multicolumn{8}{|c|}{ Panel B: Very low weight $(<1,500 \mathrm{~g})$} \\
\hline Crisis & $\begin{array}{l}0.760 * * \\
(0.338)\end{array}$ & $\begin{array}{l}0.761 * * \\
(0.339)\end{array}$ & $\begin{array}{l}0.730 * * \\
(0.309)\end{array}$ & $\begin{array}{l}0.766 * * \\
(0.340)\end{array}$ & $\begin{array}{l}0.757 * * \\
(0.340)\end{array}$ & $\begin{array}{l}0.734 * * \\
(0.309)\end{array}$ & $\begin{array}{l}0.634 * * \\
(0.285)\end{array}$ \\
\hline Mean & 2.103 & 2.103 & 2.103 & 2.103 & 2.103 & 2.103 & 2.103 \\
\hline \multicolumn{8}{|l|}{ Panel C: Pre-term } \\
\hline Crisis & $\begin{array}{l}0.741 * * \\
(0.356)\end{array}$ & $\begin{array}{l}0.735 * * \\
(0.357)\end{array}$ & $\begin{array}{l}0.701 * * \\
(0.333)\end{array}$ & $\begin{array}{l}0.758 * * \\
(0.354)\end{array}$ & $\begin{array}{l}0.707 * * \\
(0.358)\end{array}$ & $\begin{array}{l}0.712 * * \\
(0.330)\end{array}$ & $\begin{array}{l}0.620^{*} \\
(0.317)\end{array}$ \\
\hline Mean & 8.957 & 8.957 & 8.957 & 8.957 & 8.957 & 8.957 & 8.957 \\
\hline Observations & 538,367 & 538,367 & 538,367 & 538,367 & 538,367 & 538,367 & 538,367 \\
\hline$\%$ mothers between $25-35$ & & $\checkmark$ & & & & $\checkmark$ & \\
\hline$\%$ mothers above 35 & & $\checkmark$ & & & & $\checkmark$ & \\
\hline Average income & & & $\checkmark$ & & & $\checkmark$ & \\
\hline Ethnicity FE & & & & & $\checkmark$ & & \\
\hline Population density & & & & $\checkmark$ & & $\checkmark$ & \\
\hline Regional trends & & & & & & & $\checkmark$ \\
\hline
\end{tabular}

The results obtained estimating (1) through a linear probability model. The dependent variable in Panel $\mathrm{A}$ is low weight, and the dependent variable in Panel B is very low weight, and the dependent variable in Panel C is preterm. The sample includes only immigrant single deliveries. Each specification controls for municipal fixed effects, conception year fixed effects, the percentage of the municipal population with a high school degree, and the percentage of the municipal population with a college degree. Models (1) (6) also include macro-area trends. The period considered (2002-2013) refers to the conception year. The conception year is defined in the text. See Table 8 for variable descriptions. The coefficients are multiplied by 100 . Standard errors are clustered at the municipal level. *** $\mathrm{p}<0.01, * * \mathrm{p}<0.05, * \mathrm{p}<0.1$

We check for any anticipatory effect by estimating the leads and lags of Eq. 1. The coefficients are plotted in Fig. 4 and confirm the soundness of our approach.

\section{Drivers}

When we investigate the main drivers of the observed effects, we move from the model in Eq. 2.

$$
\text { Health }_{i m T}=\delta G R_{m t} * D_{*}+\lambda D_{*}+\omega G R_{m t}+\tau_{m}+\gamma_{t}+\beta_{a}\left(\rho_{a} * t\right)+E_{m t}^{\prime} \sigma+A g e_{m t}^{\prime} \pi+\epsilon_{i m T}
$$




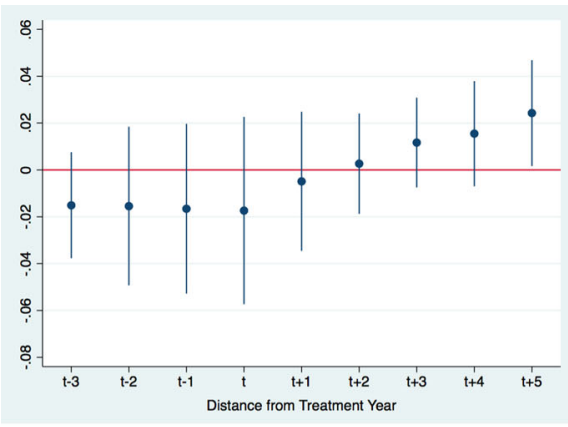

(a)

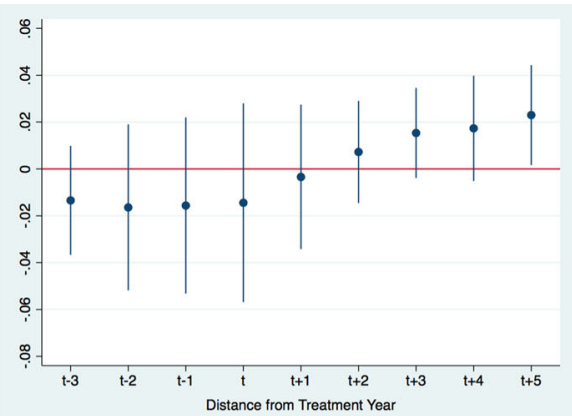

(b)

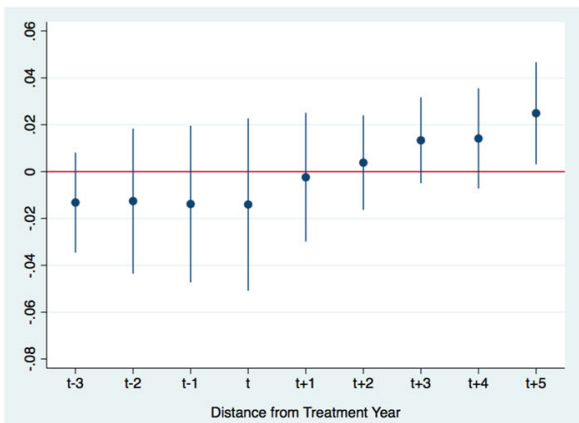

(c)

Fig. 4 Leads and lags. Notes: The figures plot the coefficients for the specified outcome in (a), (b) and (c) of a leads and lags regression of the effects of the Great Recession. $t$ is the first conception year in which the recession was recorded at the municipal level. a Low Weight b Very Low Weight $\mathbf{c}$ Pre-term

where $D$ is the dummy for each driver, which is equal to 1 if the value of the variable is above the median of its distribution in 2007 and 0 otherwise and it can be defined at the municipal level $(*=m)$, at the ethnic group level $(*=g)$ or at both $(*=g m)$. We use the 2007 distribution to exploit the conditions of the network before the spread of the recession. We consider 7 different $D$ that capture the size and organization of the ethnic network and the diversification of employment of each group. The results of the heterogeneities for the sample of singletons are reported in Table 3. The results on Italians' newborns, which we use as a placebo, are shown in Table 12.

\subsection{Size}

The size of an ethnic group is a standard measure used in the literature to measure the strength of a network. Accordingly, for each newborn whose mother resides in municipality $m$, we calculate the share of her mother group $g$ on the total number of residents. A higher share can capture a stronger community support and the potential redistribution of help during a recession, but it could also mean less access to external sources of support; ex-ante, the impact of the mother group is difficult to say. 
Table 3 Ethnic network and birth outcomes

\begin{tabular}{|c|c|c|c|c|c|c|c|}
\hline & $\begin{array}{l}\text { (1) } \\
\text { Distance to the } \\
\text { closest } \\
\text { associations }\end{array}$ & $\begin{array}{l}\text { (2) } \\
\text { Number of } \\
\text { immigrant } \\
\text { associations }\end{array}$ & $\begin{array}{l}(3) \\
\text { Ethnic } \\
\text { association }\end{array}$ & $\begin{array}{l}\text { (4) } \\
\text { Ethnic } \\
\text { density }\end{array}$ & $\begin{array}{l}(5) \\
\text { Overqualified } \\
\text { females }\end{array}$ & $\begin{array}{l}\text { (6) } \\
\text { Affected } \\
\text { sector }\end{array}$ & $\begin{array}{l}\text { (7) } \\
\text { Number of } \\
\text { local exiting } \\
\text { firms }\end{array}$ \\
\hline \multicolumn{8}{|c|}{ Panel A: Low weight $(<2,500 \mathrm{~g})$} \\
\hline & Near & Less & Low & No & No & Unaffected & Less \\
\hline Crisis & $\begin{array}{l}-2.007^{*} \\
(0.976)\end{array}$ & $\begin{array}{l}1.178 * * \\
(0.567)\end{array}$ & $\begin{array}{l}0.984 * \\
(0.522)\end{array}$ & $\begin{array}{l}0.516 \\
(0.491)\end{array}$ & $\begin{array}{l}-0.467 \\
(0.788)\end{array}$ & $\begin{array}{l}-0.093 \\
(0.693)\end{array}$ & $\begin{array}{l}0.731^{*} \\
(0.376)\end{array}$ \\
\hline & Far & More & High & Yes & Yes & Affected & More \\
\hline Crisis & $0.765 * *$ & 0.636 & 0.406 & $0.759 * *$ & $0.761 * *$ & $0.756^{* *}$ & $0.898^{*}$ \\
\hline$p$-value & 0.041 & 0.191 & 0.212 & 0.042 & 0.042 & 0.043 & 0.061 \\
\hline Difference & $\begin{array}{l}2.772 * * * \\
(0.925)\end{array}$ & $\begin{array}{l}-0.816^{*} \\
(0.454)\end{array}$ & $\begin{array}{l}-0.578 \\
(0.385)\end{array}$ & $\begin{array}{l}0.243 \\
(0.421)\end{array}$ & $\begin{array}{l}1.228^{*} \\
(0.706)\end{array}$ & $\begin{array}{l}0.850 \\
(0.602)\end{array}$ & $\begin{array}{l}0.167 \\
(0.382)\end{array}$ \\
\hline
\end{tabular}

Panel B: Very low weight $(<1,500 \mathrm{~g})$

$\begin{array}{llllllll} & \text { Near } & \text { Less } & \text { No } & \text { Low } & \text { No } & \text { Unaffected } & \text { Less } \\ \text { Crisis } & -0.208 & 1.071^{*} & 0.959^{*} & 0.559 & 0.055 & -0.162 & 0.738^{* *} \\ & (0.530) & (0.549) & (0.504) & (0.413) & (0.480) & (0.441) & (0.340) \\ & \text { Far } & \text { More } & \text { Yes } & \text { High } & \text { Yes } & \text { Affected } & \text { More } \\ \text { Crisis } & 0.770^{* *} & 0.498^{* *} & 0.550^{* *} & 0.781^{* *} & 0.775^{* *} & 0.782^{* *} & 1.420^{* * *} \\ p \text {-value } & 0.023 & 0.020 & 0.023 & 0.019 & 0.022 & 0.021 & 0.000 \\ & & & & & & & \\ \text { Difference } & 0.979 * * & -0.573 & -0.408 & 0.222 & 0.719 * * & 0.945^{* * *} & 0.682^{* * * *} \\ & (0.434) & (0.441) & (0.396) & (0.187) & (0.334) & (0.284) & (0.254)\end{array}$

PANEL C: Pre-term

$\begin{array}{llllllll} & \text { Near } & \text { Less } & \text { Low } & \text { No } & \text { No } & \text { Unaffected } & \text { Less } \\ \text { Crisis } & -1.610^{*} & 1.214^{* *} & 0.898^{*} & 0.840 & -0.254 & -0.221 & 0.727^{* *} \\ & (0.949) & (0.526) & (0.490) & (0.520) & (0.766) & (0.675) & (0.359) \\ & \text { Far } & \text { More } & \text { Yes } & \text { High } & \text { Yes } & \text { Affected } & \text { More } \\ \text { Crisis } & 0.766^{* *} & 0.341 & 0.515 & 0.730^{* *} & 0.761^{* *} & 0.764 * * & 1.155^{* *} \\ p \text {-value } & 0.031 & 0.228 & 0.317 & 0.042 & 0.032 & 0.032 & 0.026 \\ & & & & & & & \\ \text { Difference } & 2.376^{* * *} & -0.873 * * & -0.383 & -0.011 & 1.015 & 0.984 * & 0.428 \\ & (0.905) & (0.425) & (0.397) & (0.418) & (0.693) & (0.596) & (0.452)\end{array}$

The results obtained estimating (2) through a linear probability model. The dependent variable in Panel A is low weight, and the dependent variable in Panel B is very low weight, and the dependent variable in Panel $\mathrm{C}$ is preterm. Each specification controls for municipal fixed effects, conception year fixed effects, macroarea trends, and the percentage of the municipal population with a high school degree, the percentage of the municipal population with a college degree. The period considered (2002-2013) refers to the conception year. The conception year is defined in the text. See Table 8 for the variable descriptions. Difference refers to the coefficient on the interaction term between crisis and the driver in consideration, $\delta$. near in Column (1), less in Columns (2) and (7), Low in Column (3), No in Columns (4)-(5), and unaffected in Column (6) refer to the coefficients on crisis, $\omega$. far in Column (1), more in Columns (2) and (7), High in Column (3), yes in Columns (4)-(5), and affected in Column (6) refer to the sum of the coefficients on crisis and the interaction term between crisis and the driver in consideration, $\omega+\delta$. Standard errors are clustered at the municipal level. The coefficients are multiplied by 100. *** $\mathrm{p}<0.01, * * \mathrm{p}<0.05, * \mathrm{p}<0.1$. 
Therefore, it is not surprising that this measure does not capture any heterogenous response as shown in Column $4 .^{9}$

\subsection{Organization}

The fact that the size of a group might not be informative might not be surprising if one considers that when the migration process of a given ethnic group is older to an area, its size becomes less important. Therefore, we also consider how well organized an ethnic group is in the municipality of residence of the mother or in its proximity. As an expression of the group's organization, we use the presence of immigrant associations, that is, voluntary organizations either established by immigrants or actively run by them. These associations can be registered at the municipal level in the registry of local associations as parts of volunteer work networks. The size of ethnic groups does not drive the creation of these associations in Italy; thus, better organized groups do not necessarily coincide with larger ethnic communities. For example, in our sample, the group size and number of associations at the municipal level have a negligible negative correlation of -0.016 . Rather than the size, the settlement patterns turn out to be more important (Caponio 2005).

Associations are important for immigrants to integrate into the hosting society and gain practical and informational support (Somerville and Goodman 2010; Caselli 2010). According to a 2006 survey by the Italian Volunteering Foundation (FIVOL), almost $60 \%$ of immigrant associations in Italy are active in the area of social assistance and provide medical and psychological support services (Frisanco 2006). Through the Ministry of Labour and Social Policies, we obtain a unique dataset on the distribution of registered immigrant associations across Italian municipalities, and we generate three variables: distance to the nearest association, number of associations, and ethnic association. The ethnic association is a dummy that takes the value of 1 if there is at least one immigrant association in the municipality of residence of the mother specific to her ethnic group. ${ }^{10}$ The distance to the nearest association measures the distance in kilometers between the centroid of the municipality of residence of the newborn and the centroid of the nearest municipality with at least one association; this considers that in many small municipalities, there might be zero

\footnotetext{
${ }^{9} \mathrm{We}$ also considered the following three additional proxies to express the ethnic composition of the reference immigrant community:ethnic group on Italian residents, ethnic group on foreign residents, and same language ethnic groups on total residents. ethnic group on Italian residents is the share of residents that belong to a given ethnic group among the Italian resident population in a given municipality, while ethnic group on foreign residents is the ratio between residents who belong to a given ethnic group and the overall number of foreign residents in a given municipality. The same language ethnic groups on total residents is the proportion of immigrant residents who share the same mother tongue among the total population in a given municipality. The results obtained confirm that size does not matter, as shown in Table 13 in the Appendix. Finally, the last column of Table 13 tests the impact of language proximity. Language is clearly a key element of integration (Chiswick and Miller 2002). As an immigrant's mother tongue is more similar to Italian, the role of the ethnic group in conveying information and providing support should become less relevant. To measure how far the official language of each ethnic group in our dataset is from Italian, we rely on the index developed by Melitz and Toubal (2014). This index is based on the scoring that the Automated Similarity Judgment Program (ASJP) assigned to each pair of languages by comparing the linguistic similarity of a set of 200 words. A higher level of language proximity is associated with a positive impact on health at birth.

${ }^{10}$ Figure 6 illustrates the distribution of immigrant associations across Italian provinces.
} 
associations. ${ }^{11}$ As a mother lives far from an organized immigrant community, the benefit that she receives from it decreases (Patacchini and Zenou 2012).

Being near a registered association (Column 1) and living in a municipality with more associations (Column 2) decrease the probability of being born at a low weight, at a very low weight, and preterm, while there is no significant effect driven by the existence of one's own ethnicity association (Column 3). ${ }^{12}$

\subsection{Diversification of employment}

For the 44 main ethnicities residing in Italy, we recover information on the overqualification of female respondents and their main sector of employment from the Labour Force Survey (ISTAT 2008). Affected sectors captures the percentage of people in each ethnicity employed in the construction and manufacturing sectors, which were the sectors most affected by the GR. Overqualified females is a dummy equal to one if the females who belong to ethnicity $i$ are overqualified more than the median value across all ethnicities. The role of the first variable is intuitive, while overqualified females captures the problem of a high level of over-qualification across immigrant communities: because immigrants accept any type of employment, they tend to be more over-qualified for their jobs than natives. Overall, immigrant women experience more over-qualification than immigrant men, and they generally struggle more with this problem in the European Union (6.5\% more likely) than in the US $(3 \%)$ (OECD/European Union 2015). ${ }^{13}$ The community might help to maintain overqualification through the channel of sector over-representation. ${ }^{14}$ Over-qualification is often associated with poor mental health.

\footnotetext{
${ }^{11}$ This means that the distance will be zero when at least one association is located in the municipality of residence.

${ }^{12}$ To rule out that the distance to the nearest association could proxy the municipal population, the distance to a highly populated municipality or the distance to a hospital, we run a set of additional heterogeneities whose results are displayed in B10 in the working paper version (Bertoli et al. 2020). Specifically, the distance to the nearest hospital measures the distance in kilometers between the centroid of the municipality of residence of the newborn and the centroid of the nearest municipality with at least one hospital. The distance to the nearest highly populated municipality measures the distance in kilometers between the centroid of the municipality of residence of the newborn and the centroid of the nearest highly populated municipality, that is, a municipality with more than the median population in our dataset (i.e., 28,459 residents). There is no significant heterogeneous response.

${ }^{13}$ According to the OECD, although the incidence of over-qualification among immigrants in general did not change as a consequence of the GR, in Italy, over-qualification increased by $10 \%$ among immigrants and by $4 \%$ among natives due to the recession (OECD/European Union 2015). The phenomenon is also associated with a high level of heterogeneity across institutions and educational patterns in the countries of origin. Nevertheless, over-qualification is very likely to become even more pronounced during economic downturns. ${ }^{14}$ For instance, in the UK, Bangladeshi and Pakistani immigrants are "disproportionately concentrated" in the trade, accommodation, and transportation sectors (Owen et al. 2015). In the US, Hispanic men are more likely to be employed in the construction sector (United States Department of Labor 2016). In France, Turkish and Tunisian immigrants work mainly in the manufacturing and service sectors (Gabrielli 2015). In Italy, Moroccans are employed in the construction sector, while Chinese are involved in trade and manufacturing, and almost the entire community of Sri Lankan immigrants work as domestic workers (ISTAT 2009). Over-representation might have several important consequences on immigrants' employment opportunities. If an immigrant's ethnic group is over-represented in a sector, then she may have a greater chance of earning a position in this specific sector but fewer outside options if this sector is struck by an economic crisis, as in a sort of lock-in situation.
} 
As an alternative to affected sectors, exiting firms is based on data obtained through the registry of the municipal chamber of commerce, which count the number of closing firms at the municipal level per economic sector. This measure combines the information on the main sector of employment per ethnic group (not necessarily manufacturing or construction) and how this sector was struck in the municipality of residence of the mother, since we can count how many firms per sector were canceled from the registry because they closed.

Worse health outcomes for immigrants' newborns are associated with higher levels of female over-qualification (Column 5), a higher involvement of the ethnic group in the main sectors affected by the crisis (Column 6), and a higher involvement in the economic sectors most affected at the municipal level (Column 7).

\section{The composition effect}

The heterogeneous effects driven by the different characteristics of an ethnic network could have several explanations, among which, since we are dealing with immigrants, there could be the decision to move. Although at the aggregate level, Italy did not experience a loss of immigrants because of the recession, there could be a relocation across municipalities and this relocation could account for our findings by changing the composition of the ethnic groups. We test this scenario by applying (1) to three outcomes. The first is the share of immigrants in the overall population (immigrant share) at the municipal level. The second is the share of female immigrants aged 15-49 years in the overall immigrant population aged 15-49 years (share of females 15-49). The third outcome is the share of immigrants aged 15-49 years in the overall immigrant population (share of immigrants 15-49). As shown in Table 14, the immigrant share decreases by less than $3 \%$, and the share of female immigrants aged 15-49 years increases by less than $1 \%$.

However, it might be that specific types of immigrants relocate. We check how this is related in particular to the distribution of immigrant associations, since it filtered the negative impact of the crisis. We estimate (2) on a set of 3 outcomes at the municipal level: the share of the healthiest groups, the share of the higher users of prenatal care, and the distribution of female newborns, to capture any in utero selection process. We proxy the healthiest groups according to the well-used measure in the literature on migration, which is the distance between the host country and the country of origin (Chiswick 1999). As the distance (from capital to capital) increases, immigrants should be more selected health wise. As a result, healthiest is constructed based on the ethnicities whose country of origin is the farthest from Italy. As a consequence of the crisis, the healthiest groups moved to municipalities near or with more associations (Table 4).

We use the data provided by the WHO on antenatal care use in the countries of origin to identify the ethnicities with the highest use of prenatal care and construct the highest consumers of prenatal. As apparent from Table 5, although it is not always precisely estimated, the heterogeneous effect suggests that where there are more 
Table 4 Healthiest groups

\begin{tabular}{|c|c|c|c|c|}
\hline & \multicolumn{2}{|l|}{ Top 5 groups } & \multicolumn{2}{|l|}{ Top 10 groups } \\
\hline & (1) & (2) & (3) & (4) \\
\hline & $\begin{array}{l}\text { Distance to the } \\
\text { closest } \\
\text { associations }\end{array}$ & $\begin{array}{l}\text { Number of } \\
\text { immigrant } \\
\text { associations }\end{array}$ & $\begin{array}{l}\text { Distance to the } \\
\text { closest } \\
\text { associations }\end{array}$ & $\begin{array}{l}\text { Number of } \\
\text { immigrant } \\
\text { associations }\end{array}$ \\
\hline \multicolumn{5}{|c|}{ Panel A: Far on population } \\
\hline & Near & Less & Near & Less \\
\hline \multirow[t]{3}{*}{ Crisis } & $0.015 * * *$ & -0.0002 & $0.018 * * *$ & 0.001 \\
\hline & $(0.006)$ & $(0.005)$ & $(0.007)$ & $(0.006)$ \\
\hline & Far & More & Far & More \\
\hline Crisis & $-0.009^{*}$ & 0.006 & $-0.012 * *$ & 0.006 \\
\hline p-value & 0.066 & 0.242 & 0.038 & 0.345 \\
\hline Difference & $\begin{array}{l}-0.024^{* * *} \\
(0.006)\end{array}$ & $\begin{array}{l}0.007 \\
(0.006)\end{array}$ & $\begin{array}{l}-0.030^{* * *} \\
(0.007)\end{array}$ & $\begin{array}{l}0.005 \\
(0.007)\end{array}$ \\
\hline \multicolumn{5}{|c|}{ Panel B: Far females on population } \\
\hline & Near & Less & Near & Less \\
\hline \multirow[t]{3}{*}{ Crisis } & $0.007^{*}$ & -0.0004 & $0.008^{* *}$ & 0.001 \\
\hline & $(0.003)$ & $(0.003)$ & $(0.004)$ & $(0.004)$ \\
\hline & Far & More & Far & More \\
\hline Crisis & -0.004 & 0.003 & -0.006 & 0.003 \\
\hline$p$-value & 0.200 & 0.358 & 0.134 & 0.525 \\
\hline Difference & $\begin{array}{l}-0.011^{* * *} \\
(0.004)\end{array}$ & $\begin{array}{l}0.003 \\
(0.004)\end{array}$ & $\begin{array}{l}-0.014 * * * \\
(0.005)\end{array}$ & $\begin{array}{l}0.002 \\
(0.004)\end{array}$ \\
\hline \multicolumn{5}{|c|}{ Panel C: Far females on female population } \\
\hline & Near & Less & Near & Less \\
\hline \multirow[t]{3}{*}{ Crisis } & $0.038^{* *}$ & 0.004 & $0.045^{* *}$ & 0.006 \\
\hline & $(0.016)$ & $(0.015)$ & $(0.019)$ & \\
\hline & Far & More & Far & More \\
\hline Crisis & -0.014 & 0.021 & -0.022 & 0.019 \\
\hline p-value & 0.374 & 0.169 & 0.248 & 0.314 \\
\hline Difference & $\begin{array}{l}-0.052 * * * \\
(0.018)\end{array}$ & $\begin{array}{l}0.018 \\
(0.017)\end{array}$ & $\begin{array}{l}-0.067 * * * \\
(0.022)\end{array}$ & $\begin{array}{l}0.013 \\
(0.021)\end{array}$ \\
\hline
\end{tabular}

The results obtained estimating (2) through a linear probability model. In Panel A, the dependent variable is the measure of far on population; In Panel B, the dependent variable is the measure of farfemales on population. In Panel $\mathrm{C}$, the dependent variable is the measure of Far Females on Female Population. In Columns (1) - (2), the dependent variable measures are constructed for the top 5 healthiest ethnic groups; In Columns (3) - (4), the dependent variable measures are constructed for the top 10 healthiest ethnic groups. Each specification controls for municipal fixed effects, conception year fixed effects, macro-area trends, the percentage of the municipal population with a high school degree, and the percentage of the municipal population with a college degree. The conception year is defined in the text. See Table 8 for the variable descriptions. Difference refers to the coefficient on the interaction term between crisis and the driver in consideration, $\delta$. near in Columns (1) and (3), and less in Columns (2) and (4), refer to the coefficients on crisis, $\omega$. far in Columns (1) and (3), and more in Columns (2) and (4), refer to the sum of the coefficients on crisis and the interaction term between Crisis and the driver in consideration, $\omega+\delta$. Standard errors are clustered at the municipal level. The coefficients are multiplied by 100 . *** $\mathrm{p}<0.01, * * \mathrm{p}<0.05$, $* \mathrm{p}<0.1$ 
Table 5 Groups with the highest use of prenatal care

\begin{tabular}{|c|c|c|c|c|}
\hline & \multicolumn{2}{|l|}{ Top 5 groups } & \multicolumn{2}{|l|}{ Top 10 groups } \\
\hline & $\begin{array}{l}\text { (1) } \\
\text { Distance to the } \\
\text { closest } \\
\text { associations }\end{array}$ & $\begin{array}{l}\text { (2) } \\
\text { Number of } \\
\text { immigrant } \\
\text { associations }\end{array}$ & $\begin{array}{l}\text { (3) } \\
\text { Distance to the } \\
\text { closest } \\
\text { associations }\end{array}$ & $\begin{array}{l}\text { (4) } \\
\text { Number of } \\
\text { immigrant } \\
\text { associations }\end{array}$ \\
\hline \multicolumn{5}{|c|}{ Panel A: Highest users on population } \\
\hline & Near & Less & Near & Less \\
\hline \multirow[t]{2}{*}{ Crisis } & $\begin{array}{l}0.010 \\
(0.007)\end{array}$ & $\begin{array}{l}-0.006 \\
(0.007)\end{array}$ & $\begin{array}{l}-0.011 \\
(0.018)\end{array}$ & $\begin{array}{l}-0.041^{* *} \\
(0.018)\end{array}$ \\
\hline & Far & More & Far & More \\
\hline Crisis & -0.012 & 0.004 & $-0.048 * * *$ & -0.018 \\
\hline$p$-value & 0.128 & 0.546 & 0.009 & 0.308 \\
\hline Difference & $\begin{array}{l}-0.022 * * \\
(0.009)\end{array}$ & $\begin{array}{l}0.011 \\
(0.009)\end{array}$ & $\begin{array}{l}-0.037 * * \\
(0.018)\end{array}$ & $\begin{array}{l}0.023 \\
(0.018)\end{array}$ \\
\hline \multicolumn{5}{|c|}{ Panel B: Highest female users on population } \\
\hline & Near & Less & Near & Less \\
\hline Crisis & $\begin{array}{l}0.008^{*} \\
(0.004) \\
\text { Far }\end{array}$ & $\begin{array}{l}-0.002 \\
(0.005) \\
\text { More }\end{array}$ & $\begin{array}{l}-0.005 \\
(0.009) \\
\text { Far }\end{array}$ & $\begin{array}{l}-0.022 * * \\
(0.009) \\
\text { More }\end{array}$ \\
\hline Crisis & -0.005 & 0.005 & $-0.027 * * *$ & -0.009 \\
\hline$p$-value & 0.287 & 0.295 & 0.005 & 0.315 \\
\hline Difference & $\begin{array}{l}-0.014 * * \\
(0.006)\end{array}$ & $\begin{array}{l}0.007 \\
(0.005)\end{array}$ & $\begin{array}{l}-0.022 * * \\
(0.009)\end{array}$ & $\begin{array}{l}0.013 \\
(0.009)\end{array}$ \\
\hline \multicolumn{5}{|c|}{ Panel C: Highest users on female population } \\
\hline & Near & Less & Near & Less \\
\hline Crisis & $\begin{array}{l}0.028 \\
(0.021) \\
\text { Far }\end{array}$ & $\begin{array}{l}-0.010 \\
(0.023) \\
\text { More }\end{array}$ & $\begin{array}{l}-0.051 \\
(0.043) \\
\text { Far }\end{array}$ & $\begin{array}{l}-0.118^{* * *} \\
(0.045) \\
\text { More }\end{array}$ \\
\hline Crisis & -0.012 & 0.024 & $-0.113^{* *}$ & -0.05 \\
\hline$p$-value & 0.616 & 0.296 & 0.017 & 0.272 \\
\hline Difference & $\begin{array}{l}-0.040 \\
(0.027)\end{array}$ & $\begin{array}{l}0.033 \\
(0.026)\end{array}$ & $\begin{array}{l}-0.062 \\
(0.043)\end{array}$ & $\begin{array}{l}0.069 \\
(0.043)\end{array}$ \\
\hline
\end{tabular}

The results obtained estimating (2) through a linear probability model. In Panel A, the dependent variable is the measure of highest users on population; In Panel B, the dependent variable is the measure of highest females users on population; In Panel $\mathrm{C}$, the dependent variable is the measure of highest females users on female population. In Columns (1) - (2), the dependent variable measures are constructed for the top 5 highest users ethnic groups; In Columns (3) - (4), the dependent variable measures are constructed for the top 10 highest users ethnic groups. Each specification controls for municipal fixed effects, conception year fixed effects, macro-area trends, the percentage of the municipal population with a high school degree, the percentage of the municipal population with a college degree. The conception year is defined in the text. See Table 8 for the variable descriptions. Difference refers to the coefficient on the interaction term between crisis and the driver in consideration, $\delta$. near in Columns (1) and (3), and less in Columns (2) and (4) refer to the coefficients on crisis, $\omega$. far in Columns (1) and (3), and more in Columns (2) and (4) refer to the sum of the coefficients on crisis and the interaction term between crisis and the driver in consideration, $\omega+\delta$. Standard errors are clustered at the municipal level. The coefficients are multiplied by 100 . *** $\mathrm{p}<0.01, * * \mathrm{p}<0.05, * \mathrm{p}<0.1$ 
Table 6 In utero selection: The share of females age zero

\begin{tabular}{lll}
\hline & $(1)$ & $(2)$ \\
& $\begin{array}{l}\text { Distance to the } \\
\text { closest associations }\end{array}$ & $\begin{array}{l}\text { Number of } \\
\text { immigrant associations }\end{array}$ \\
\hline & Near & Less \\
Crisis & $-3.020^{* * *}$ & $-1.333^{* *}$ \\
& $(0.600)$ & $(0.651)$ \\
Crisis & Far & More \\
$p$-value & 0.457 & $-1.402^{* *}$ \\
& 0.512 & 0.027 \\
Difference & $3.477^{* * *}$ & -0.070 \\
& $(0.735)$ & $(0.714)$ \\
\hline
\end{tabular}

The results obtained estimating (2) through a linear probability model. The dependent variable is share of females aged zero. Each specification controls for municipal fixed effects, conception year fixed effects, macro-area trends, the percentage of the municipal population with a high school degree, and the percentage of the municipal population with a college degree. The conception year is defined in the text. See Table 8 for the variable descriptions. Difference refers to the coefficient on the interaction term between crisis and the driver in consideration, $\delta$. near in Column (1), and less in Column (2) refer to the coefficients on crisis, $\omega$. far in Columns(1), and More in Column (2) refer to the sum of the coefficients on crisis and the interaction term between crisis and the driver in consideration, $\omega+\delta$. Standard errors are clustered at the municipal level. The coefficients are multiplied by 100 . *** $\mathrm{p}<0.01, * * \mathrm{p}<0.05,{ }^{*} \mathrm{p}<0.1$

associations or in their proximity, there are larger shares of the highest consumers of prenatal care.

A final phenomenon that could affect our results is in utero selection: males are weaker than females in utero; therefore, the incidence of newborn girls increases during economic downturns (Trivers and Willard 1973; Krackow 2002), which explains the higher incidence of low weight births. Consistent with the hypothesis of in utero selection, the share of females is higher when there are fewer associations or the mother is far from them (Table 6).

\section{Conclusion}

In the context of Italy, which is one of the countries that was most affected during the GR, we provide new evidence on the effect of the recession on three measures of health at birth: the probability of low birth weight (less than 2,500g); the probability of very low birth weight (less than $1,500 \mathrm{~g}$ ); and the probability of being born premature. The GR increases the probability of newborns being low weight by $8.7 \%$, the probability of being very low weight by $36 \%$, and the probability of being premature by $8.3 \%$. Our results are consistent with different specifications and the constructions of the GR spread. Compared with immigrants' newborns, the negative effects of the recession on Italians' newborns are milder. 
We further examine different possible drivers to explain the effects of the GR on immigrants' newborns. We show that the burdens of the crisis on immigrants' newborns were driven by their ethnicity involvement in the sectors most affected by the crisis, and the lack of diversification of the economic sectors in which their ethnicity is employed. The same channels do not exert any effects on Italians' newborns, which confirms the presence of network effects rather than neighborhood effects.

Substantial evidence emphasizes that health conditions at birth have not only longlasting effects on health but also socio-economic outcomes later in life (Helgertz and Nilsson 2019). Our findings suggest that relative to natives, immigrants in Italy start off their life-cycle with more disadvantages during a time of economic crisis. This could translate into widening the socio-economic gap between natives and immigrants later on. To this point, it is important for the policies that aim to ease the economic burden during an economic downturn episode to weigh in the extra obstacles that minorities are subject to. Furthermore, since immigrants who are locked in the most affected economic sectors and immigrants who receive less support from associations are worse off the most, pro-immigrant policies may consider to prioritize these groups.

\section{Appendix}

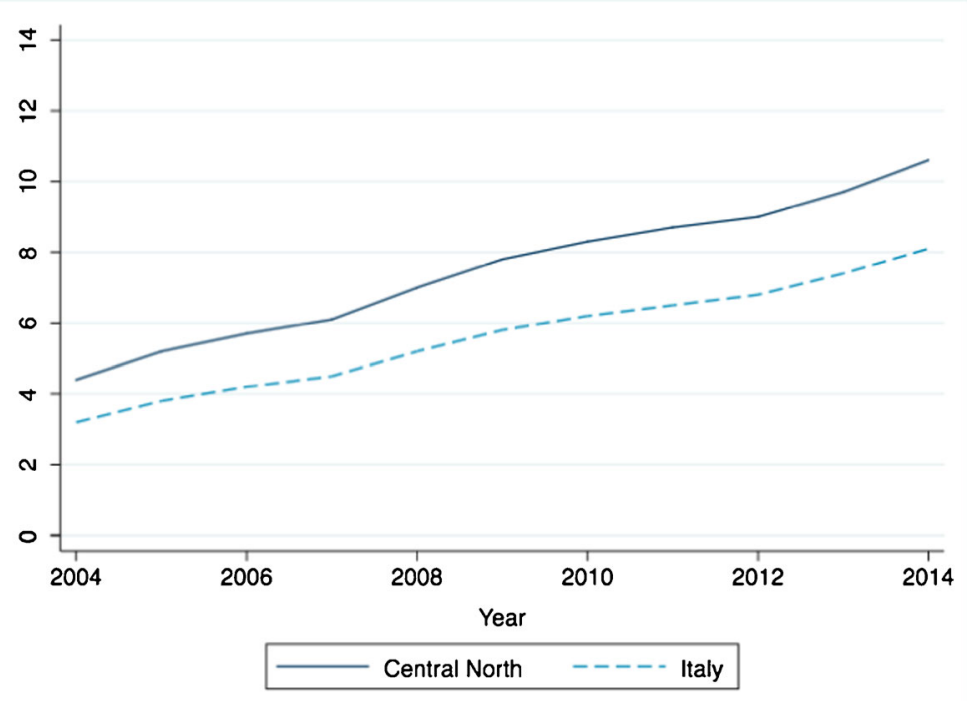

Fig. 5 Immigrants per 100 residents. Notes: The figure plots the trend over time of the number of immigrants per 100 residents at the national level and considering only Northern and Central regions 
Table 7 Effects of the GR on birth rates

Full sample

Singletons

(1)

(2)

\begin{tabular}{lll}
\hline Crisis & -0.012 & 0.026 \\
& $(0.121)$ & $(0.120)$ \\
Mean & 8.256 & 8.148 \\
Observations & 53,584 & 53,528 \\
$\%$ mothers between ages 25-35 & $\checkmark$ & $\checkmark$ \\
$\%$ mothers above age 35 & $\checkmark$ & $\checkmark$ \\
\hline
\end{tabular}

The results obtained estimating (1) at the municipal level. The dependent variable is the birth rates. In Column (1), the sample includes all immigrant deliveries; in Column (2), the sample includes only immigrant singletons. Each specification controls for municipal fixed effects, conception year fixed effects, macroarea trends, the percentage of the municipal population with a high school degree, the percentage of the municipal population with a college degree. The period considered (2002-2013) refers to the conception year. The conception year is defined in the text. See Table 8 for the variable descriptions. Standard errors are clustered at the municipal level. The coefficients are multiplied by 100 . *** $\mathrm{p}<0.01, * * \mathrm{p}<0.05$, * $\mathrm{p}<0.1$

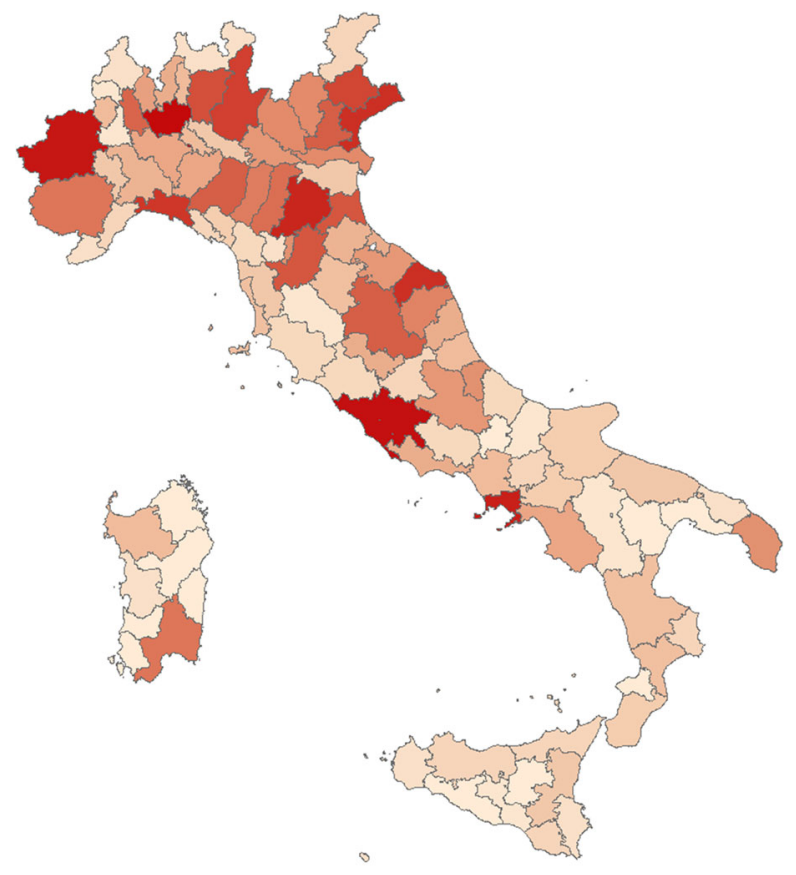

Fig. 6 Distribution of association. Notes: Number of immigrant associations at the provincial level. Darker areas indicate higher values 


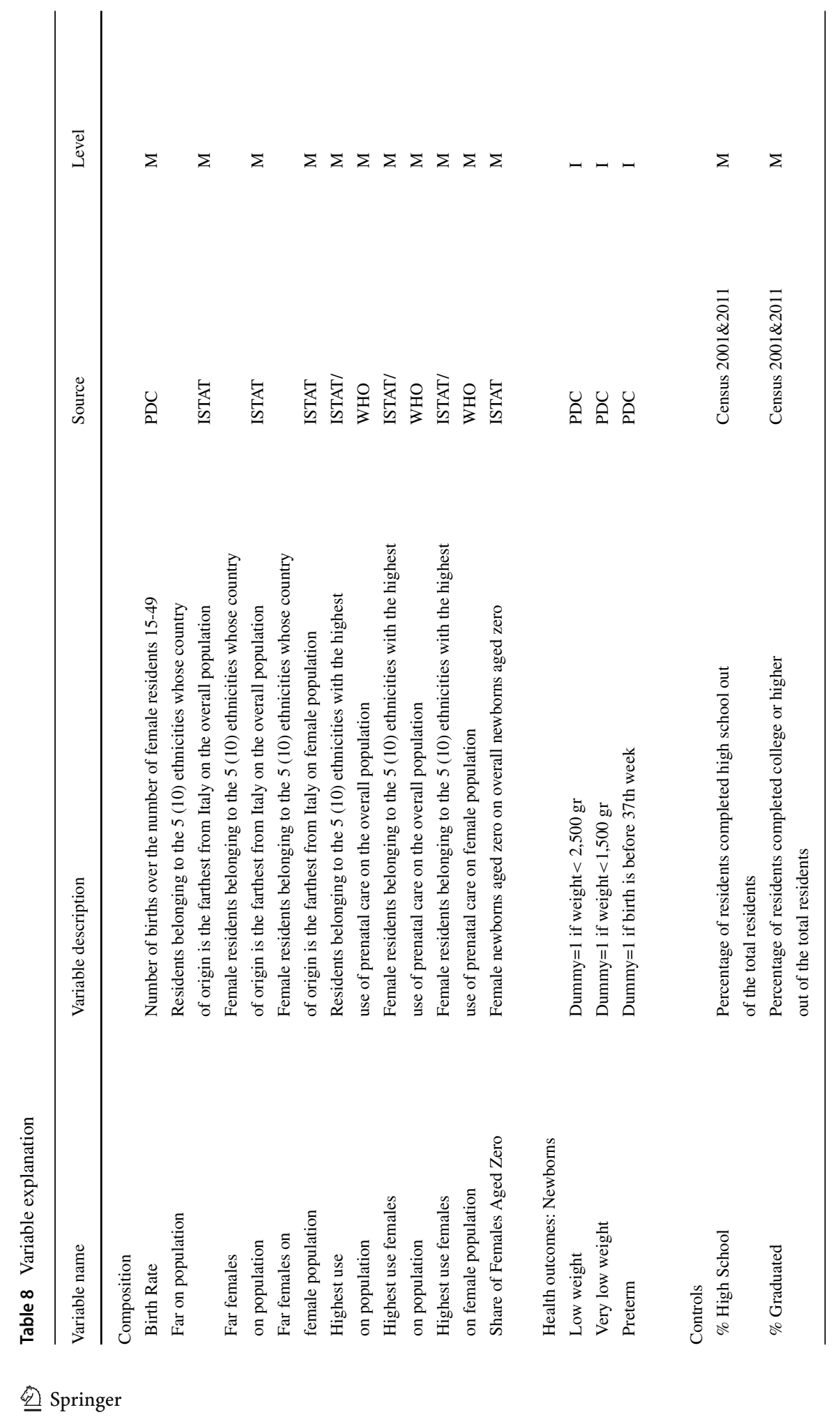




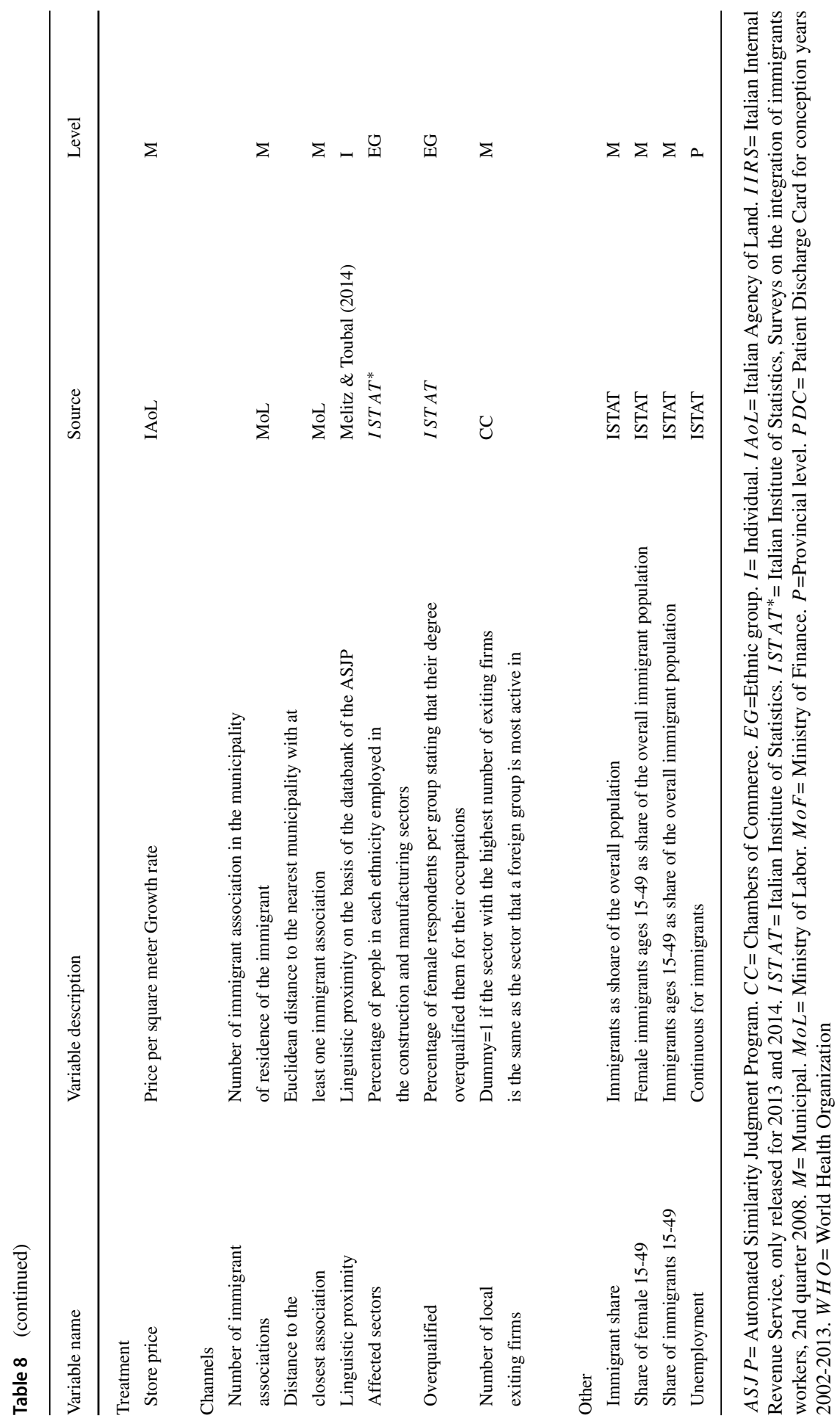


Table 9 Effects of the GR on birth outcomes - Full sample
(1)
(2)
(3)
(4)
(5)
(6)
(7)

Panel A: Low weight $(<2,500 \mathrm{~g})$

$\begin{array}{lllllllll}\text { Crisis } & 0.711^{*} & 0.707 * & 0.679 * & 0.726 * & 0.677 * & 0.690 * * & 0.609 * \\ & (0.375) & (0.376) & (0.349) & (0.374) & (0.377) & (0.346) & (0.329) \\ \text { Mean } & 8.547 & 8.547 & 8.547 & 8.547 & 8.547 & 8.547 & 8.547\end{array}$

Panel B: Very low weight $(<1,500 \mathrm{~g})$

$\begin{array}{lllllllll}\text { Crisis } & 0.757 * * & 0.758^{* *} & 0.727 * * & 0.763 * * & 0.755^{* *} & 0.731 * * & 0.631 * * \\ & (0.338) & (0.339) & (0.309) & (0.340) & (0.339) & (0.308) & (0.284) \\ \text { Mean } & 2.112 & 2.112 & 2.112 & 2.112 & 2.112 & 2.112 & 2.112\end{array}$

Panel C: Pre-term

\begin{tabular}{|c|c|c|c|c|c|c|c|}
\hline Crisis & $\begin{array}{l}0.710^{* *} \\
(0.358)\end{array}$ & $\begin{array}{l}0.705 * * \\
(0.359)\end{array}$ & $\begin{array}{l}0.669 * * \\
(0.336)\end{array}$ & $\begin{array}{l}0.728 * * \\
(0.356)\end{array}$ & $\begin{array}{l}0.677 * \\
(0.361)\end{array}$ & $\begin{array}{l}0.681 * * \\
(0.332)\end{array}$ & $\begin{array}{l}0.595^{*} \\
(0.319)\end{array}$ \\
\hline Mean & 9.066 & 9.066 & 9.066 & 9.066 & 9.066 & 9.066 & 9.066 \\
\hline Observations & 539,927 & 539,927 & 539,927 & 539,927 & 539,927 & 539,927 & 539,927 \\
\hline$\%$ mothers between ages $25-35$ & & $\checkmark$ & & & & $\checkmark$ & \\
\hline$\%$ mothers above age 35 & & $\checkmark$ & & & & $\checkmark$ & \\
\hline Average income & & & $\checkmark$ & & & $\checkmark$ & \\
\hline Ethnicity FE & & & & & $\checkmark$ & & \\
\hline Population density & & & & $\checkmark$ & & $\checkmark$ & \\
\hline Regional trends & & & & & & & $\checkmark$ \\
\hline
\end{tabular}

The esults obtained estimating (1) through a linear probability model. the dependent variable in Panel A is low weight; the dependent variable in Panel B is very low weight, and the dependent variable in Panel $\mathrm{C}$ is preterm. The sample includes all immigrant deliveries. Each specification controls for municipal fixed effects, conception year fixed effects, the percentage of municipal the population with a high school degree, and the percentage of the municipal population with a college degree. Models (1) - (6) also include macro-area trends. The period considered (2002-2013) refers to the conception year. The conception year is defined in the text. See Table 8 for the variable descriptions. The coefficients are multiplied by 100 . Standard errors are clustered at the municipal level. *** $\mathrm{p}<0.01, * * \mathrm{p}<0.05, * \mathrm{p}<0.1$ 
Table 10 Effects of the GR on birth outcomes - Single deliveries sample Municipality and LHA Cluster
(1)
(2)
(3)
(4)
(5)
(6)
(7)

Panel A: Low weight $(<2,500 \mathrm{~g})$

$\begin{array}{llllllll}\text { Crisis } & 0.736^{*} & 0.732 * & 0.706^{*} & 0.750^{*} & 0.701 * & 0.715^{*} & 0.630^{*} \\ & (0.394) & (0.395) & (0.370) & (0.394) & (0.397) & (0.367) & (0.346) \\ \text { Mean } & 8.433 & 8.433 & 8.433 & 8.433 & 8.433 & 8.433 & 8.433\end{array}$

Panel B: Very low weight $(<1,500 \mathrm{~g})$

$\begin{array}{llllllll}\text { Crisis } & 0.760 * * & 0.761 * * & 0.730 * * & 0.766^{* *} & 0.757 * * & 0.734 * * & 0.634 * * \\ & (0.368) & (0.369) & (0.341) & (0.371) & (0.370) & (0.341) & (0.313) \\ \text { Mean } & 2.103 & 2.103 & 2.103 & 2.103 & 2.103 & 2.103 & 2.103\end{array}$

Panel C: Pre-term

\begin{tabular}{|c|c|c|c|c|c|c|c|}
\hline Crisis & $\begin{array}{l}0.741^{*} \\
(0.378)\end{array}$ & $\begin{array}{l}0.735^{*} \\
(0.379)\end{array}$ & $\begin{array}{l}0.701 * * \\
(0.357)\end{array}$ & $\begin{array}{l}0.758 * * \\
(0.376)\end{array}$ & $\begin{array}{l}0.707 * \\
(0.381)\end{array}$ & $\begin{array}{l}0.712 * * \\
(0.353)\end{array}$ & $\begin{array}{l}0.620^{*} \\
(0.338)\end{array}$ \\
\hline Mean & 8.957 & 8.957 & 8.957 & 8.957 & 8.957 & 8.957 & 8.957 \\
\hline Observations & 538,367 & 538,367 & 538,367 & 538,367 & 538,367 & 538,367 & 538,367 \\
\hline$\%$ mothers between $25-35$ & & $\checkmark$ & & & & $\checkmark$ & \\
\hline$\%$ mothers above 35 & & $\checkmark$ & & & & $\checkmark$ & \\
\hline Average income & & & $\checkmark$ & & & $\checkmark$ & \\
\hline Ethnicity FE & & & & & $\checkmark$ & & \\
\hline Population density & & & & $\checkmark$ & & $\checkmark$ & \\
\hline Regional trends & & & & & & & $\checkmark$ \\
\hline
\end{tabular}

The results obtained estimating (1) through a linear probability model. Dependent variable in Panel A is low weight; dependent variable in Panel B is very low weight; dependent variable in Panel C is preterm. The sample includes only immigrant single deliveries. Each specification controls for municipal fixed effects, conception year fixed effects, the percentage of municipal the population with a high school degree, and the percentage of the municipal population with a college degree. Models (1) - (6) also include macro-area trends. The period considered (2002-2013) refers to the conception year. The conception year is defined in the text. See Table 8 for the variable descriptions. The coefficients are multiplied by 100 . Standard errors are clustered at the LHA level. *** $\mathrm{p}<0.01, * * \mathrm{p}<0.05, * \mathrm{p}<0.1$ 
Table 11 Effects of the GR on birth outcomes - Single delivery sample of Italians' newborns

\begin{tabular}{|c|c|c|c|c|c|c|}
\hline & (1) & (2) & (3) & (4) & $(5)$ & (6) \\
\hline \multicolumn{7}{|l|}{ Panel A: Low weight $(<2,500 \mathrm{~g})$} \\
\hline Crisis & $\begin{array}{l}0.435 * * * \\
(0.137)\end{array}$ & $\begin{array}{l}0.423 * * * \\
(0.137)\end{array}$ & $\begin{array}{l}0.416^{* * * *} \\
(0.129)\end{array}$ & $\begin{array}{l}0.440 * * \\
(0.136)\end{array}$ & $\begin{array}{l}0.409 * * * \\
(0.128)\end{array}$ & $\begin{array}{l}0.414 * * * \\
(0.139)\end{array}$ \\
\hline Mean & 8.181 & 8.181 & 8.181 & 8.181 & 8.181 & 8.181 \\
\hline \multicolumn{7}{|l|}{ Panel B: Very low weight $(<1,500 \mathrm{~g})$} \\
\hline Crisis & $\begin{array}{l}0.335 * * * \\
(0.126)\end{array}$ & $\begin{array}{l}0.333^{* * * *} \\
(0.126)\end{array}$ & $\begin{array}{l}0.320^{* * *} \\
(0.114)\end{array}$ & $\begin{array}{l}0.336^{* * * *} \\
(0.126)\end{array}$ & $\begin{array}{l}0.319^{* * * *} \\
(0.114)\end{array}$ & $\begin{array}{l}0.335^{* *} \\
(0.131)\end{array}$ \\
\hline Mean & 1.586 & 1.586 & 1.586 & 1.586 & 1.586 & 1.586 \\
\hline \multicolumn{7}{|l|}{ Panel C: Pre-term } \\
\hline Crisis & $\begin{array}{l}0.318 * * \\
(0.132)\end{array}$ & $\begin{array}{l}0.304^{* *} \\
(0.132)\end{array}$ & $\begin{array}{l}0.295 * * \\
(0.123)\end{array}$ & $\begin{array}{l}0.325^{* *} \\
(0.131)\end{array}$ & $\begin{array}{l}0.290 * * \\
(0.122)\end{array}$ & $\begin{array}{l}0.289 * * \\
(0.133)\end{array}$ \\
\hline Mean & 8.466 & 8.466 & 8.466 & 8.466 & 8.466 & 8.466 \\
\hline Observations & $3,038,443$ & $3,038,443$ & $3,038,443$ & $3,038,443$ & $3,038,443$ & $3,038,443$ \\
\hline$\%$ mothers between ages $25-35$ & & $\checkmark$ & & & $\checkmark$ & \\
\hline$\%$ mothers above age 35 & & $\checkmark$ & & & $\checkmark$ & \\
\hline Average income & & & $\checkmark$ & & $\checkmark$ & \\
\hline Population density & & & & $\checkmark$ & $\checkmark$ & \\
\hline Regional trends & & & & & & $\checkmark$ \\
\hline
\end{tabular}

The results obtained estimating (1) through a linear probability model. The dependent variable in Panel $\mathrm{A}$ is low weight, and the dependent variable in Panel B is very low weight, and the dependent variable in Panel $\mathrm{C}$ is preterm. The sample includes only single Italian deliveries. Each specification controls for municipal fixed effects, conception year fixed effects, the percentage of the municipal population with a high school degree, and the percentage of the municipal population with a college degree. Models (1) - (6) also include macro-area trends. The period considered (2002-2013) refers to the conception year. The conception year is defined in the text. See Table 8 for the variable descriptions. The coefficients are multiplied by 100. Standard errors are clustered at the municipal level. *** $\mathrm{p}<0.01, * * \mathrm{p}<0.05, * \mathrm{p}<0.1$ 
Table 12 Ethnic network and birth outcomes - Single delivery sample of Italians' newborns

\begin{tabular}{|c|c|c|c|c|c|}
\hline & $\begin{array}{l}\text { (1) } \\
\text { Distance to the } \\
\text { closest } \\
\text { associations }\end{array}$ & $\begin{array}{l}\text { (2) } \\
\text { Number of } \\
\text { immigrant } \\
\text { associations }\end{array}$ & $\begin{array}{l}\text { (4) } \\
\text { Ethnic } \\
\text { density }\end{array}$ & $\begin{array}{l}(5) \\
\text { Affected } \\
\text { sector }\end{array}$ & $\begin{array}{l}\text { (6) } \\
\text { Number of } \\
\text { local exiting } \\
\text { firms }\end{array}$ \\
\hline \multicolumn{6}{|c|}{ Panel A: Low weight $(<2,500 \mathrm{~g})$} \\
\hline & Near & Less & Low & Unaffected & Less \\
\hline \multirow[t]{2}{*}{ Crisis } & $\begin{array}{l}0.468 * * * \\
(0.135)\end{array}$ & $\begin{array}{l}0.349 * \\
(0.520)\end{array}$ & $\begin{array}{l}0.506 * * * \\
(0.193)\end{array}$ & $\begin{array}{l}0.523 * * * \\
(0.130)\end{array}$ & $\begin{array}{l}0.417 * * \\
(0.201)\end{array}$ \\
\hline & Far & More & High & Affected & More \\
\hline Crisis & $0.395 * *$ & $0.486 * * *$ & $0.375 * * *$ & $0.346 *$ & $0.442 * * *$ \\
\hline p-value & 0.040 & 0.000 & 0.079 & 0.197 & 0.001 \\
\hline Difference & $\begin{array}{c}-0.072 \\
(0.181)\end{array}$ & $\begin{array}{l}0.137 \\
(0.167)\end{array}$ & $\begin{array}{l}-0.131 \\
(0.193)\end{array}$ & $\begin{array}{l}-0.177 \\
(0.193)\end{array}$ & $\begin{array}{l}0.025 \\
(0.159)\end{array}$ \\
\hline \multicolumn{6}{|c|}{ Panel B: Very low weight $(<1,500 \mathrm{~g})$} \\
\hline & Near & Less & Low & Unaffected & Less \\
\hline \multirow[t]{2}{*}{ Crisis } & $\begin{array}{l}0.302 * * * \\
(0.097)\end{array}$ & $\begin{array}{l}0.365 * \\
(0.187)\end{array}$ & $\begin{array}{l}0.375 * * \\
(0.188)\end{array}$ & $\begin{array}{l}0.297 * * * \\
(0.093)\end{array}$ & $\begin{array}{l}0.386 * * \\
(0.191)\end{array}$ \\
\hline & Far & More & High & Affected & More \\
\hline Crisis & $0.376^{* *}$ & $0.317 * * *$ & $0.301 * * *$ & $0.375^{*}$ & $0.317 * * *$ \\
\hline p-value & 0.046 & 0.002 & 0.002 & 0.051 & 0.004 \\
\hline Difference & $\begin{array}{l}0.073 \\
(0.147)\end{array}$ & $\begin{array}{l}-0.048 \\
(0.128)\end{array}$ & $\begin{array}{l}-0.074 \\
(0.149)\end{array}$ & $\begin{array}{l}0.178 \\
(0.165)\end{array}$ & $\begin{array}{l}-0.069 \\
(0.118)\end{array}$ \\
\hline \multicolumn{6}{|c|}{ Panel C: Pre-term } \\
\hline & Near & Less & Low & Unaffected & Less \\
\hline Crisis & $\begin{array}{l}0.364 * * * \\
(0.127)\end{array}$ & $\begin{array}{l}0.300 \\
(0.192)\end{array}$ & $\begin{array}{l}0.371 * * \\
(0.186)\end{array}$ & $\begin{array}{l}0.370 * * * \\
(0.121)\end{array}$ & $\begin{array}{l}0.332 * \\
(0.196)\end{array}$ \\
\hline & Far & More & High & Affected & More \\
\hline Crisis & 0.260 & $0.328 * * *$ & $0.271 * *$ & 0.264 & $0.313 * *$ \\
\hline$p$-value & 0.163 & 0.010 & 0.045 & 0.170 & 0.014 \\
\hline Difference & $\begin{array}{l}-0.103 \\
(0.171)\end{array}$ & $\begin{array}{l}0.028 \\
(0.165)\end{array}$ & $\begin{array}{l}-0.100 \\
(0.418)\end{array}$ & $\begin{array}{l}-0.105 \\
(0.185)\end{array}$ & $\begin{array}{l}-0.019 \\
(0.157)\end{array}$ \\
\hline
\end{tabular}

The results obtained estimating (2) through a linear probability model. The dependent variable in Panel A is low weight, and the dependent variable in Panel B is very low weight, and the dependent variable in Panel $\mathrm{C}$ is preterm. Each specification controls for municipal fixed effects, conception year fixed effects, macroarea trends, the percentage of the municipal population with a high school degree, and the percentage of the municipal population with a college degree. The period considered (2002-2013) refers to the conception year. The conception year is defined in the text. See Table 8 for the variable descriptions. Difference refers to the coefficient on the interaction term between crisis and the driver in consideration, $\delta$. near in Column (1), less in Columns (2) and (6), low in Column (4), and unaffected in Column (5) refer to the coefficients on crisis, $\omega$. Far in Column (1), more in Columns (2) and (6), high in Column (4), and affected in Column (5) refer to the sum of the coefficients on crisis and the interaction term between crisis and the driver in consideration, $\omega+\delta$. Standard errors are clustered at the municipal level. The coefficients are multiplied by 100 . *** $\mathrm{p}<0.01, * * \mathrm{p}<0.05, * \mathrm{p}<0.1$ 
Table 13 Additional heterogeneous effects

\begin{tabular}{|c|c|c|c|c|}
\hline & $\begin{array}{l}\text { (1) } \\
\text { Ethnic group on } \\
\text { Italian residents }\end{array}$ & $\begin{array}{l}\text { (2) } \\
\text { Ethnic group on } \\
\text { foreign residents }\end{array}$ & $\begin{array}{l}\text { (3) } \\
\text { Same language ethnic } \\
\text { groups on total residents }\end{array}$ & $\begin{array}{l}(4) \\
\text { Language } \\
\text { proximity }\end{array}$ \\
\hline \multicolumn{5}{|c|}{ Panel A: Low weight $(<2,500 \mathrm{~g})$} \\
\hline & Low & Low & Low & Far \\
\hline \multirow[t]{3}{*}{ Crisis } & 0.576 & 0.392 & 0.661 & $1.088^{* *}$ \\
\hline & $(0.496)$ & $(0.732)$ & $(0.626)$ & $(0.452)$ \\
\hline & High & High & High & Near \\
\hline Crisis & $0.754 * *$ & $0.751^{* *}$ & 0.744 & $0.969 * *$ \\
\hline$p$-value & 0.043 & 0.041 & 0.039 & 0.024 \\
\hline Difference & $\begin{array}{l}0.178 \\
(0.326)\end{array}$ & $\begin{array}{l}0.359 \\
(0.547)\end{array}$ & $\begin{array}{l}0.082 \\
(0.418)\end{array}$ & $\begin{array}{l}-0.119 * * \\
(0.053)\end{array}$ \\
\hline \multicolumn{5}{|c|}{ Panel B: Very low weight $(<1,500 \mathrm{~g})$} \\
\hline & Low & Low & Low & Far \\
\hline \multirow[t]{2}{*}{ Crisis } & $\begin{array}{l}0.618 \\
(0.421)\end{array}$ & $\begin{array}{l}0.467 \\
(0.678)\end{array}$ & $\begin{array}{l}0.499 \\
(0.560)\end{array}$ & $\begin{array}{l}1.082 * * * \\
(0.409)\end{array}$ \\
\hline & High & High & High & Near \\
\hline Crisis & $0.776^{* *}$ & $0.773^{* *}$ & 0.787 & $0.999 * *$ \\
\hline$p$-value & 0.020 & 0.019 & 0.014 & 0.011 \\
\hline Difference & $\begin{array}{l}0.158 \\
(0.188)\end{array}$ & $\begin{array}{l}0.306 \\
(0.470)\end{array}$ & $\begin{array}{l}0.288 \\
(0.303)\end{array}$ & $\begin{array}{l}-0.082^{* *} \\
(0.035)\end{array}$ \\
\hline \multicolumn{5}{|c|}{ Panel C: Pre-term } \\
\hline & Low & Low & Low & Far \\
\hline \multirow[t]{2}{*}{ Crisis } & $\begin{array}{l}0.905^{*} \\
(0.514)\end{array}$ & $\begin{array}{l}0.299 \\
(0.734)\end{array}$ & $\begin{array}{l}0.669 \\
(0.601)\end{array}$ & $\begin{array}{l}1.163 * * * \\
(0.422)\end{array}$ \\
\hline & High & High & High & Near \\
\hline Crisis & $0.723 * *$ & $0.760^{* *}$ & $0.748^{* *}$ & $1.006^{* *}$ \\
\hline$p$-value & 0.043 & 0.030 & 0.030 & 0.014 \\
\hline Difference & $\begin{array}{l}-0.183 \\
(0.402)\end{array}$ & $\begin{array}{l}0.460 \\
(0.582)\end{array}$ & $\begin{array}{l}0.079 \\
(0.421)\end{array}$ & $\begin{array}{l}-0.157 * * * \\
(0.051)\end{array}$ \\
\hline
\end{tabular}

The results obtained estimating (2) through a linear probability model. The dependent variable in Panel A is low weight, and the dependent variable in Panel B is very low weight, and the dependent variable in Panel $\mathrm{C}$ is preterm. Each specification controls for municipal fixed effects, conception year fixed effects, macroarea trends, the percentage of the municipal population with a high school degree, the percentage of the municipal population with a college degree. The period considered (2002-2013) refers to the conception year. The conception year is defined in the text. See Table 8 for the variable descriptions. Difference refers to the coefficient on the interaction term between crisis and the driver in consideration, $\delta$. Low in Columns (1) - (3), far in Column (4), refer to the coefficients on crisis, w. High in Columns (1) - (3), near in Column (4), refer to the sum of the coefficients on Crisis and the interaction term between crisis and the driver in consideration, $\omega+\delta$. Standard errors are clustered at the municipality level. The coefficients are multiplied by 100 . *** $\mathrm{p}<0.01, * * \mathrm{p}<0.05, * \mathrm{p}<0.1$ 
Table 14 Effects of the GR on the immigrant population

\begin{tabular}{llll}
\hline & $(1)$ & $(2)$ & $(3)$ \\
& $\begin{array}{l}\text { Immigrant } \\
\text { Share }\end{array}$ & $\begin{array}{l}\text { Share of } \\
\text { Females } 15-49\end{array}$ & $\begin{array}{l}\text { Share of } \\
\text { Immigrants 15-49 }\end{array}$ \\
\hline Crisis & $-0.175^{* * *}$ & $0.337^{*}$ & 0.153 \\
& $(0.045)$ & $(0.191)$ & $(0.210)$ \\
Observations & 53,528 & 53,528 & 53,528 \\
Mean & 6.093 & 50.591 & 69.471 \\
\hline
\end{tabular}

The results obtained estimating (1) at the municipal level through a linear probability model. The dependent variable in Column (1) is immigrant share, the dependent variable in Column (2) is share of females 15-49, the dependent variable in Column (3) is share of immigrants 15-49. Each specification controls for municipal fixed effects, conception year fixed effects, macro-area trends, the percentage of municipal population with a high school degree, the percentage of municipal population with a college degree. The period considered (2002-2013) refers to the conception year. The conception year is defined in the text. See Table 8 for the variable descriptions. Standard errors are clustered at the municipality level. Coefficients are multiplied by 100 . *** $\mathrm{p}<0.01, * * \mathrm{p}<0.05, * \mathrm{p}<0.1$

Acknowledgments We are grateful to the suggestions of the editor in chief, Klaus F. Zimmermann, and two anonymous referees that improved the paper. We are thankful to Yaa Akosa Antwi, Diogo Britto, Christopher Carpenter, Calogero Guccio, Maarten Lindeboom, Mario Macis, Catia Nicodemo, Giacomo Pignataro, Marcello Sartarelli, Judit Vall-Castello, and Tianyi Wang for their comments and suggestions on previous versions of this paper. We also thank the participants at the Petralia Workshop of Economics 2017, IX Workshop on Institution, Individual Behavior and Economic Outcomes (Alghero 2018), The Young Economists' Meeting (Brno 2018), EuHEA 2018, the 2019 IV Immigration, Health, and Wellbeing Workshop (University of Pittsburg), the 2019 Essen Health Conference, and the participants to the seminar at the Research Institute of Industrial Economics (IFN-Stockholm), University of Alicante, Johns Hopkins University, University of Catania, University of Economics Prague, University of Manchester, University of Milan, University of Pavia, and CRES-University Pompeu Fabra for their comments.

Funding Open access funding provided by Università degli Studi di Milano within the CRUI-CARE Agreement.

\section{Declarations}

Conflict of Interests The authors declare that they have no conflicts of interest.

Open Access This article is licensed under a Creative Commons Attribution 4.0 International License, which permits use, sharing, adaptation, distribution and reproduction in any medium or format, as long as you give appropriate credit to the original author(s) and the source, provide a link to the Creative Commons licence, and indicate if changes were made. The images or other third party material in this article are included in the article's Creative Commons licence, unless indicated otherwise in a credit line to the material. If material is not included in the article's Creative Commons licence and your intended use is not permitted by statutory regulation or exceeds the permitted use, you will need to obtain permission directly from the copyright holder. To view a copy of this licence, visit http://creativecommonshorg/licenses/by/4.0/. 


\section{References}

Aparicio A, Gonzalez L, Vall Castello J (2020) Newborn health and the business cycle: the role of birth order. Econ Human Biol 37:100836. https://doi.org/10.1016/j.ehb.2019.100836

Angelini V, Mierau JO (2014) Born at the right time? Childhood health and the business cycle. Soc Sci Med 109:35-43. https://doi.org/10.1016/j.socscimed.2014.03.014

Bhalotra S (2010) Fatal fluctuations? Cyclicality in infant mortality in India. J Dev Econ 93(1):7-19. https://doi.org/10.1016/j.jdeveco.2009.03.006

Battisti M, Peri G, Romiti A (2018) Dynamic effects of co-ethnic networks on immigrants' economic. NBER Working Paper Series, n. 22389. http://www.nber.org/papers/w22389

Bertoli P, Grembi V, Nguyen TLB (2020) Birth in hard times when you belong to minorities. GLO Discussion Paper, No. 729, Global Labor Organization (GLO), Essen. http://hdl.handle.net/10419/ 226828

Bertrand M, Duflo E, Mullainathan S (2004) How much should we trust differences-in-differences estimates? Q J Econ 119(1):249-275. https://doi.org/10.1162/003355304772839588

Bozzoli C, Quintana-Domeque C (2014) The weight of the crisis: evidence from newborns in Argentina. Rev Econ Stat 96(3):550-62. https://doi.org/10.1162/REST_a_00398

Brenøe A, Molitor R (2018) Birth order and health of newborns. J Popul Econ 31:363-395. https://doi.org/10.1007/s00148-017-0660-1

Busalacchi J, Calzolari G, Chiurco F, D’Alessandro L, D’Alessio A, de Mottoni G, Di Saverio M, Fasano G, Ferri P, Guzzo I, Mangano G, Moretti S, Mosca M, Racioppo A (2009) Risposte Europee all'Attuale Crisi Socio-economica (Dossier Paesi). ISFOL and FSE, Ministero del Lavoro e delle Politiche Sociali, Italy. https://inapp.infoteca.it/bw5ne2/opac.aspx?WEB=INAP\&IDS=17074

Caltabiano M, Comolli CL, Rosina A (2017) The effect of the Great Recession on permanent childlessness in Italy. Demographic Res 37(20):635-668. https://doi.org/10.4054/DemRes.2017.37.20

Caponio T (2005) Policy networks and immigrants' associations in Italy: the cases of Milan, Bologna and Naples. J Ethn Migr Stud 31(5):931-950. https://doi.org/10.1080/13691830500177891

Cavicchioli M, Pistoresi B (2019) Unfolding the relationship between mortality, economic fluctuations, and health in Italy. Eur J Health Econ 21(3):351-362. https://doi.org/10.1007/s10198-019-01135-1

Caselli M (2010) Integration, participation, identity: immigrant associations in the province of Milan. Int Migr 48:58-78. https://doi.org/10.1111/j.1468-2435.2009.00530.x

Cavalieri M, Ferrante L (2016) Does fiscal decentralization improve health outcomes? Evidence from infant mortality in Italy. Soc Sci Med 164:74-88. https://doi.org/10.1016/j.socscimed.2016.07.017

Chiswick B (1999) Are immigrants favorably self-selected? Am Econ Rev 89(2):181-185. https://www. jstor.org/stable/117103

Chiswick B, Miller P (2002) Immigrant earnings: Language skills, linguistic concentrations and the business cycle. J Popul Econ 15:31-57. https://doi.org/10.1007/PL00003838

Currie J, Schwand H (2014) Short-and long-term effects of unemployment on fertility. Proc Natl Acad Sci 111(41):14734-14739. https://doi.org/10.1073/pnas.1408975111

D'Errico A, Piccinelli C, Sebastiani G (2019) Unemployment and mortality in a large Italian cohort. J Public Health (Oxf). https://doi.org/10.1093/pubmed/fdz100

Damm AP (2009) Ethnic Enclaves and Immigrant Labor Market Outcomes: Quasi-Experimental Evidence. J Labor Econ 27(2):281-314. https://doi.org/10.1086/599336

Dehejia R, Lleras-Muney A (2004) Booms, busts, and babies' health. Q J Econ 119(3):1091-1130. https://doi.org/10.1162/0033553041502216

De Cao E, McCormick B, Nicodemo C (2019) Is the health of English babies worse in recessions?. IZA Discussion Papers 12568, Institute for the Study of Labor (IZA). http://eprints.lse.ac.uk/102270/1/ De_Cao_does_unemployment_worsen_babies_health_published.pdf

Dettling LJ, Kearney MS (2014) House prices and birth rates: the impact of the real estate market on the decision to have a baby. J Public Econ 110:82-100. https://doi.org/10.1016/j.jpubeco.2013.09.009

De Vogli R, Vieno A, Lenzi M (2014) Mortality due to mental and behavioral disorders associated with the Great Recession (2008-10) in Italy: a time trend analysis. Eur J Public Health 24(3):419-421. https://doi.org/10.1093/eurpub/ckt173

Di Pietro G (2018) Revisiting the impact of macroeconomic conditions on health behaviours. Econ Human Biol 28:173-181. https://doi.org/10.1016/j.ehb.2017.11.001

Di Quirico R (2010) Italy and the global economic crisis. Bull Ital Polit 2(2):3-19. https://www.gla.ac.uk/ media/Media_191024_smxx.pdf 
Edin P, Fredriksson P, Aslund O (2003) Ethnic enclaves and the economic success of immigrants evidence from a natural experiment. Q J Econ 118(1):329-357. https://doi.org/10.1162/0033553 0360535225

Eurofond (2010) Effects of economic crisis on Italian economy. https://www.eurofound.europa.eu/print/ observatories/eurwork/articles/effects-of-economic-crisis-on-italia

Ensor T, Cooper S, Davidson L, Fitzmaurice A, Graham WJ (2010) The Impact of Economic Recession on Maternal and Infant Mortality: Lessons from History. Bmc Public Health 10:727-27. https://doi.org/10.1186/1471-2458-10-727

Farré L (2015) New evidence on the healthy immigrant effect. J Popul Econ 29:365-394. https://doi.org/10.1007/s00148-015-0578-4

Frisanco R (2006) Volontariato sotto la lente: lo scenario del volontariato organizzato alla luce della quarte rilevazione FIVOL 2006, Fondazione Euroopa Occupazione e Volontariato, Impresa e Solidarietá, Roma. Available at: http://www.fondazioneterzopilastrointernazionale.it/wp-content/uploads/ 2014/12/1-REPORTODFINALEODVITALIA2006.pdf

Gabrielli L (2015) Corridor report on France: the case of Tunisian and Turkish immigrants. INTERACT, Migration Policy Center, European University Institute, n.8. https://cadmus.eui.eu/bitstream/handle/ 1814/36059/INTERACT-RR-2015

Helgertz J, Nilsson A (2019) The effect of birth weight on hospitalizations and sickness absences: a longitudinal study of Swedish siblings. J Popul Econ 32:153-178. https://doi.org/10.1007/s00148018-0706-Z

Hoynes H, Miller DL, Schaller J (2012) Who suffers during recessions? J Econ Perspect 26(3):27-48. https://doi.org/10.1257/jep.26.3.27

ISTAT (2008) Rilevazione delle Forze Lavoro. L'integrazione dei migranti e dei loro discendenti nel mercato del lavoro II Trimestre 2008. (Labor Force Detection. Integration of migrants and their descendants into the labor market) https://www.istat.it/it/archivio/8263

ISTAT (2009) L'integrazione nel lavoro degli stranieri e dei naturalizzati italiani. https://www.istat.it/it/ files//2011/01/Integrazione_lavoro_stranieri1.pdf

Krackow S (2002) Why parental sex ratio manipulation is rare in higher vertebrates. Ethology 108:10411056. https://doi.org/10.1046/j.1439-0310.2002.00843.x

Lin CYY, Edvinsson L, Chen J, Beding T (2013) National intellectual capital and the financial crisis in Greece, Italy, Portugal, and Spain, Springer, New York

Lindo JM (2015) Aggregation and the estimated effects of economic conditions on health. J Health Econ 40:83-96. https://doi.org/10.1016/j.jhealeco.2014.11.009

Mattei G, Ferrari S, Pingani L, Rigatelli M (2014) Short-term effects of the 2008 great recession on the health of the italian population: an ecological study. Soc Psychiatry Psychiatr Epidemiol 49(6):851858. https://doi.org/10.1007/s00127-014-0818-z

Melitz J, Toubal F (2014) Native language, spoken language, translation and trade. J Int Econ 93(2):351363. https://doi.org/10.1016/j.jinteco.2014.04.004

Moscone F, Tosetti E, Vittadini G (2016) The impact of precarious employment on mental health: The case of Italy. Soc Sci Med 158:86-95. https://doi.org/10.1016/j.socscimed.2016.03.008

OECD/European Union (2015) Indicators of immigrant integration 2015: setting in. OECD Publishing, Paris. https://doi.org/10.1787/9789264234024-en

Owen D, Gambin L, Green A, Li Y (2015) Projecing Employment by Ethnic Group to 2022. Joseph Rowntree Foundation Report. https://www.jrf.org.uk/report/projecting-employment-ethnic-group-2022

Patacchini E, Zenou Y (2012) Ethnic networks and employment outcomes. Reg Sci Urban Econ 42(6):938-949. https://doi.org/10.1016/j.regsciurbeco.2012.01.004

Royer H (2009) Separated at girth: US twin estimates of the effects of birth weight. Am Econ J Appl Econ 1:49-85. https://doi.org/10.1257/app.1.1.49

Schaller J (2016) Booms, busts, and fertility: testing the becker model using gender-specific labor demand. J Human Resour 51(1):1-29. https://doi.org/10.3368/jhr.51.1.1

Simeoni S, Frova L, De Curtis M (2019) Inequalities in infant mortality in Italy. Ital J Pediatr 45(1):11-11. https://doi.org/10.1186/s13052-018-0594-6

Somerville W, Goodman SW (2010) The role of networks in the development of UK migration policy. Polit Stud 58:951-970. https://doi.org/10.1111/j.1467-9248.2009.00814.x

Trivers RL, Willard DE (1973) Natural selection of parental ability to vary the sex ratio of offspring. Science 179(4068):90. https://doi.org/10.1126/science.179.4068.90 
United States Department of Labor BureauofLaborStatistics (2016) Labor force characteristics by race and ethnicity. https://www.bls.gov/opub/reports/race-and-ethnicity/2016/home.htm

van den Berg GJ, Modin B (2013) Economic conditions at birth, birth weight, ability, and the causal path to cardiovascular mortality. IZA Discussion Papers 7605, Institute for the Study of Labor (IZA). http:// ftp.iza.org/dp7605.pdf

van den Berg GJ, Lindeboom M, Lopez M (2009) Inequality in individual mortality and economic conditions earlier in life. Soc Sci Med 69:1360-1367. https://doi.org/10.1016/j.socscimed.2009.08.012

van den Berg GJ, Pinger PR, Schoch J (2016) Instrumental variable estimation of the casual effect of hunger early in life on health later in life. Econ J 126:465-506. https://doi.org/10.1111/ecoj.12250

Xie Y, Gough M (2011) Ethnic enclaves and the earnings of immigrants. Demography 48(4):1293-1315. https://doi.org/10.1007/s13524-011-0058-8

Publisher's note Springer Nature remains neutral with regard to jurisdictional claims in published maps and institutional affiliations. 